\title{
Chapter 11 \\ Fashioning Cosmology: Franco \\ Burgersdijk as the Author of the Dutch \\ Tractatus de sphaera
}

\author{
Marius Buning
}

\begin{abstract}
In 1625, the highest authorities in the province of Holland prescribed the use of De sphaera in all the regional Latin schools. For the occasion, they decided that a new edition of the famous text by Johannes de Sacrobosco was needed, primarily to purify the textbook of its "barbaric" Latin. The task of editing the text was assigned to Leiden professor Franco Burgersdijk. In what follows, I situate Burgersdijk's 1626 edition of De sphaera in the broader context of Leiden Aristotelianism, discussing the relationship between religion, educational practices, and astronomy in the first decades of Dutch independence. Teasing out some of the differences with the other contemporary manuals circulating on the market, I argue that Burgersdijk's version of Sacrobosco's textbook must be seen as an attempt to make the Dutch less dependent on Catholic literature and modes of knowledge production.
\end{abstract}

\section{Life and Work}

Burgersdijk was a farmer's son, born in 1590 in De Lier, Delfland, not far from The Hague, where the Dutch authorities had declared their independence from landlord Philip II (1527-1598) and the Spanish Habsburg Empire in $1581 .{ }^{1}$ According to his first biographer, the young Burgersdijk attended the Latin school at Amersfoort (1604-1606) and the Delft Gymnasium (1606-1610), where he first became familiar with the art of logic and rhetoric. Like many farmer's sons, he then attended the University of Leiden to study theology. He was thoroughly immersed in the art of disputation and undertook private lessons with the famous scholastic adversary of

\footnotetext{
${ }^{1}$ I am referring to the Plakkaat van Verlatinghe (1581), the unofficial declaration of independence. On the history of the Dutch Republic, see for instance (Israel 1995). On Burgersdijk, see (Dibon 1954, 90-119; van Meurs 1625, 340-42; Bos and Krop 1993; Molhuysen et al. 1927, 229-31).
}

\author{
M. Buning $(\bowtie)$ \\ Freie Universität Berlin, Berlin, Germany \\ e-mail: marius.buning@fu-berlin.de
}


René Descartes (1596-1650), Gisbertus Voetius (1589-1676), who was at the time still the vice-principal of the Staten Collegie (a boarding school for students of theology established by the States of Holland, the highest provincial authorities). By the time he finished his education, around 1614, Burgersdijk was conversant in Latin and Greek, in Roman History, and in the salient details of the Protestant faith. The next step in his education was undertaking a grand tour, in the course of which he found himself for some time in the Academy of Saumur. There, he worked with the Scottish philosopher Mark Duncan (ca. 1570-1640) and the strict Calvinist theologian Franciscus Gomarus (1563-1641), who had fled to the Huguenot University in 1611 to escape his Dutch Arminian opponents. And it was in Saumur, in 1614, that Burgersdijk would first attain to a professorship in philosophy.

Burgersdijk's academic career cannot be understood without some degree of insight into the religious troubles that flared up in the period right after the young Dutch Republic had agreed on an armistice with the Spanish enemy. The ink on the treaty, concluded in 1609, was not yet dry when the followers of the Leiden theology professor Jacobus Arminius (1560-1609) requested the States of Holland to call for a church synod in order to decide on a number of sensitive religious issues in the series of heated debates between Arminius and Gomarus (contingent on their respective leaders, followers of both theologians were also called Gomarists or Arminians). The issue at stake in the debates, which later took a violent turn, was the correct interpretation of the Holy Scriptures; whereas the Arminians reckoned with the possibility of a very moderate form of free will, the Gomarists insisted on a strict interpretation of Calvin's notion of double predestination and denied man any form of influence on his future salvation. ${ }^{2}$

The ecclesiastical conflict had been deeply intermingled with Dutch internal power politics from the start. Whereas the Gomarists favored a form of state religion-having the Calvinist Basel in mind as an ideal-the Arminians were generally more liberal in their views on the relationship between the church and the state. ${ }^{3}$ The disagreements lingered on for years, suddenly escalating in 1618, when the central authorities of the federal Dutch state, the States-General, agreed to summon an international synod despite the objections of the mighty province of Holland, run mostly by regents who supported the Arminian faction. The States of Holland reacted by raising a military force to restore order, which brought them in direct conflict with Stadtholder Prince Maurice of Orange (1567-1625). In what has been identified as nothing less than "a coup," Maurice set off on a military campaign and quickly took power of the entire country. ${ }^{4}$ The political skirmishes concluded dramatically with the beheading of the Land's Advocate of Holland, Johan van

\footnotetext{
${ }^{2}$ Arminians were willing to pretend a certain ignorance on the issue, and to speak of God's 'stationary' or 'permitting' will (voluntas remissa, pace Perkins and others). The Arminians were strongly influenced by the Spanish scholastics on this point, and notably by Suarez and Molina (Dekker 1993, 115, 188).

${ }^{3}$ Speaking in general terms, one could say that the Arminians consisted of people from the regent class, whereas the Gomarists were found in greater numbers among the common people (Prak 2005, 31).

${ }^{4}$ For more details, see (Israel 1995, 426-57).
} 
Oldenbarnevelt (1547-1619), on the Inner Court in The Hague. The religious bickering was settled with the international Synod of Dort, which had its last meeting on the $9^{\text {th }}$ of May 1619.5 The Synod of Dort finally ruled in favor of the Gomarists and some two hundred Arminian preachers were dismissed from office (de Nijs and Beukers 2002, 311). ${ }^{6}$

Arminianism was rooted out at all levels in the Republic, including at the universities. With numerous positions opening up in the "purified" University of Leiden, Burgersdijk immediately saw his chance to return to Holland. The university initially offered him an extraordinarius professorship in logic, which he accepted on the $25^{\text {th }}$ of March 1620, obtaining the title of Magister philosophiae on the $31^{\text {st }}$ of March 1620, during a promotion ceremony led by the famous astronomer and mathematician Willebrord Snellius (1580-1626). In November 1620, ethics was added to Burgersdijk's teaching duties, and on the $9^{\text {th }}$ of February 1621, Burgersdijk was promoted to ordinarius professor. In 1623, he finally completed his theological education by defending a disputation entitled "The Clarity of the Bible and Its Interpretation" (Krop 2014, 2).

Meanwhile, Burgersdijk had maintained an ongoing interest in natural philosophy. In two series of disputations, the first held in 1623 and the second in 1627, his students had dealt with the Aristotelian knowledge corpus on natural knowledge. It brought him into direct conflict with the Leiden Professor Jacchaeus, his former teacher, who bitterly complained at the Leiden Senate that Burgersdijk was overstepping the boundaries of his discipline (Dibon 1954, 97). Jacchaeus had held the chair of natural philosophy since 1617 and remained active in that capacity until his death in $1628 .^{7}$ Soon after the chair had become vacant, on the $9^{\text {th }}$ of May 1628 , Burgersdijk exchanged it with his chair in ethics. It was under these circumstances that

...Burgersdijk devoted two manuals [to physics]. The Idea is conceived as a "guide" to be used in disputations, presenting the subject matter in definitions and short theses. By referring only to "new" authorities such as Jacopo Zabarella, Benedict Pereira, Franciscus Toletus, and the commentators of Coimbra, Burgersdijk stated as his goal to open the debate on the "text of Aristotle." In the more extensive Collegium, the same doctrinal tradition is elaborated in a synthetic order. (Krop 2014, 3) ${ }^{8}$

\footnotetext{
${ }^{5}$ The first meeting of the Synod of Dort had been on the $13^{\text {th }}$ of November 1618.

${ }^{6}$ The Synod of Dort confirmed the authority of the Belgic Confession and the Heidelberg Catechism, and drew up ninety-three new canonical rules. Furthermore, the Synod decided upon several other issues, such as the production of a Bible translation into the vernacular funded by the States-General (which eventually resulted in the 1637 Statenbijbel).

${ }^{7}$ The Scot Gilbert Jack (Lat. Jacchaeus) had first held the chairs for logic and ethics at the University of Leiden $(1605,1607)$, before publishing his lnstitutiones physicae in 1614, which has been identified as "the first work of any note on physics to issue from Leiden's faculty" (Ruestow 1973, 14). Jacchaeus was made a full professor of natural philosophy in 1617. On Jack, see (Smolenaars 2004). He "taught a reformed Aristotelianism which also made use of recent scholarship, including Zabarella, Suarez, and the Coimbra commentators" (Mijers 2017, 91). Burgersdijk would do the same. He had also taken over the teaching duties of Jacchaeus, when the latter was suspended for 3 months on the suspicion of Arminian sympathies in 1619, in the wake of the Synod of Dort.

${ }^{8}$ On Burgersdijk's Physics, see also (Dibon 1954, 90-119; Ruestow 1973, 5-33). An overview of Burgersdijk's publications can be found in (Bos and Krop 1993, 167).
} 
Although Burgersdijk did recognize the birth of new stars (Ruestow 1973, 30) and that heavens act on the terrestrial world by occult qualities, not just by light and motion (Vermij 2016, 293; Vermij 2002, 132), the ensemble of his natural philosophy has nevertheless been characterized as "the Aristotelian principles in an extreme and simplistic (and distorted) rendering...presented largely in the guise of first matter and substantial form" (Ruestow 1973, 22). Indeed, it was not for his natural philosophy that he would be remembered when he died on the $19^{\text {th }}$ of February 1635, eleven days after the end of his last term as Rector Magnificus of Leiden University. ${ }^{9}$

Instead, the Leiden Professor became known for his compendium on logic, the Institvtionvm logicarvm libri duo (Leiden, Commelius, 1626), which, "[a]lthough abhorred by students[,]...lingered in the curriculum of the British universities well into the eighteenth century" (Krop 2014, 1). ${ }^{10}$ Like his other manuals, the Institutionum was characterized by a strong inclination towards order and method. ${ }^{11}$ Although an Aristotelian in heart and soul, Burgersdijk deplored the messy presentation in the work of the Stagerite. On the other hand, he believed that in the work of humanists such as Valla, Agricola, and Ramus, where method did prevail, content had fallen behind. It was thus best to follow the example of Bartholomaeus Keckermann (1672-1609) by adopting the method of Ramus and the material of Aristotle. Burgersdijk claimed that, by doing so, he followed in the footsteps of his former mentor in Saumur, Mark Duncan. ${ }^{12}$

Aside from his works on logic and natural philosophy, Burgersdijk wrote a number of compendia on moral and political thought, again heavily inspired by Aristotle. If one was to summarize his academic career in one sentence, one could say that Burgersdijk was perhaps not a very original thinker, but a dedicated educator who brought stability to Leiden University in the wake of the Synod of Dort. It is indeed in this light that we must also read Burgersdijk's 1626 edition of Sacrobosco's textbook on the Sphaera - a booklet produced under the direct order of the Dutch political authorities.

\footnotetext{
${ }^{9}$ Burgersdijk was the rector of Leiden University in 1629, 1630, and 1634.

${ }^{10}$ On the influence of Burgersdijk in England, see also (Feingold 1993). On the status of Philosophy course at Leiden University (Sassen 1959; Dibon 1954, 71-76). Like De sphaera, the Institutionum was commissioned by the States of Holland in the framework of the 1625 School Order, which was intended to provide unity in the Dutch educational program.

${ }^{11}$ On "order" in the Philosphiae naturalis, see (Dibon 1954, 95). On the general emphasis on "method" at the time, see (Gilbert 1963).

${ }^{12}$ On the influence of Duncan on Burgersdijk, see (Prost 1907, 42-44). On the Scottish influence on Dutch universities, see (Mijers 2017). On Leiden University more generally, see (Otterspeer 2000; Ruestow 1973; Wiesenfeldt 2002).
} 


\section{The Schoolorde (1625)}

In the hive-off of the Spanish Habsburg Empire, the Northern Netherlands became a kind of federal republic, in which seven semi-independent provinces were each represented with one vote in the Assembly of the States-General seated in The Hague. The provinces, of which Holland was by far the most powerful, were in turn managed by a provincial assembly led by an individual Stadtholder (whose office was a strange remnant from the Habsburg period, resembling a cross between a prince and a president). In reality, the Stadtholder of Holland observed the Stadholdership of the majority of other provinces.

In addition, there were many other interest groups in the political domain, including the different trading companies and various congregations within the Dutch Reformed Church, which met at irregular intervals in provincial synods. It was at one of these provincial synods that the call for a reform of the Dutch educational system could first be heard. During the South Holland Synod held in Rotterdam in 1581 , members of the congregation expressed their explicit concern about the lack of properly schooled ministers. The radical break with the Catholic Habsburg landlord in their eyes called for immediate joint action by the Republican authorities to ensure the establishment of a single Dutch reformed identity. Though similar sentiments could be heard at various other provincial synods between 1583 and 1618, the political leadership did not take any action. ${ }^{13}$ The issue of religious education was taken up again at the international Synod of Dort, where various ecclesiastical representatives insisted that the States-General should be urged to bring "unity in the education of the Youth, in particular in the rules of Grammar, Dialectics and Rhetoric." ${ }^{14}$ An official request to the States-General was indeed submitted on the $18^{\text {th }}$ of May 1619; yet again it did not prompt any action. The congregation continued to complain about the matter at various synods, and in 1622, a commission was even appointed "to study the school order made in the Pfaltz, in Gelderland, in Groningen and elsewhere" in order to come up with a proposal to reform the educational system. ${ }^{15}$ Eventually, it all had little effect.

Simultaneously, complaints about the inadequate level of secondary education could be heard at Leiden University, where the professors claimed that students were not well prepared to follow even the most basic university courses in Latin. They attributed this shortcoming to the fragmentation of pre-university school programs and argued that school pupils would benefit from having a more standardized

\footnotetext{
${ }^{13}$ Kuiper provides a list with no less than sixteen instances of complaint (Kuiper 1958, 39-40).

14 “...eenparigheyt gehouden werde in de onderwijsinghe van de Jeught, voor al in de regelen van de Grammatica, Dialectica en Retorica." Kerkelijk Placaetboek van N. Wilkens (1722), I, p. 127 sq. As cited in (Kuiper 1958, 40). All translations of the source material are by the author unless otherwise stated.

${ }^{15}$ (Kuiper 1958, 40): “...visiteren ende confereren de schoolordeninghe, die gemaect syn in de CHURFORSTELICHE PFALTZ, in GELDERLAND, in GROENINGEN ende elders om daeruyt een project te maecken." The commission was formed during the South Holland synod of Gorinchem in July 1622.
} 
regimen of studies. ${ }^{16}$ After various failed efforts, the Senate of the University, in 1624, impressed upon the Assembly of the States of Holland the necessity of concrete measures. Clearly aware of the earlier efforts in the various synods, a plan was handed in that would (1) guarantee the quality of the secondary educational program and (2) ensure that the youth could move from city to city without having to use new books at every location (Kuiper 1958, 48-51). Should new measures not be implemented, the Senate warned, it was "to be feared that the young adolescents will degenerate again ad barbariam." 17

The States of Holland gave a full and sympathetic consideration to the complaints of the University, asking the Curators to draft a program that could be implemented in the Latin Schools in the province. On the $4^{\text {th }}$ of February 1625, the Curators organized a meeting with some deputies of the University Senate and of the Holland Synodes in order to come up with a proposal. The deputies of the University Senate were Antonius Walaeus (1573-1638), Antonius Thysius the Elder (1565-1640), Gerhard Johannes Vossius (1577-1649), Petrus Cunaeus (1586-1638), Daniel Heinsius (1580-1655), and Burgersdijk, who was thus closely involved in the making of the order from the very start. Indeed, no less than three members of the senatorial committee managed to put their own books on the obligatory reading list; it seems not to have bothered the commission nominated on the $22^{\text {nd }}$ of July 1625 to study the proposals made by the University. ${ }^{18}$ The draft program was approved and on the $1^{\text {st }}$ of October 1625, the States of Holland enacted the School Order (Schoolorde) that would remain in force until the early nineteenth century.

\section{Print and Privilege}

The School Order meticulously prescribed the use of specific books on specific hours, laying out an intense program for school-aged children (ca. twelve to eighteen years old) from Monday morning through to Saturday afternoon. Willem Frijhoff has provided such an eloquent and concise overview of this program that it deserves to be quoted here in full:

When the child had completed the writing classes, he entered the sixth (lowest) class, where he learned declensions and conjugations and parts of speech (the Rudimenta), and practiced reading Erasmus's dialogues. Subject matter for the fifth class included the letters of Cicero and the Disticha of Cato, as well as Erasmus's book of etiquette. The fourth class brought more Cicero, some Terence, and — as first exercises in prosody—Ovid's Tristia and Virgil's

\footnotetext{
${ }^{16}$ Kuiper convincingly identifies examination methods based on memorization as one of the main "culprits" in this entire problematic (Kuiper 1958, 45).

${ }^{17}$ (Kuiper 1958, 49): “...staet te vreesen, dat de jonge jeugt wederom soude mogen ad barbariem vervallen."

${ }^{18}$ The committee appointed by the States of Holland consisted of representatives from Dordrecht, Haarlem, Alkmaar, Amsterdam, and Hoorn (all cities with famed Latin Schools).
} 
Bucolica. From that point on the pupil also delved seriously into Greek. The focus of the second class was on rhetoric, explained with the aid of Vossius's handbook, and more Cicero, who was now studied in great detail. The program of the highest class included the logic of the Leiden professor Franco Burgersdijk, as well as Horace and Homer, and again the inescapable Cicero. The top group of the highest class was initiated into the world of the quadrivium (music, arithmetic, geometry, and astronomy), with lessons in ethics, the arithmetic of Gemma Frisius, and the Sphaera of Johannes de Sacrobosco. (Frijhoff and Spies $2004,245)^{19}$

With the existence of a fixed catalogue with books that had to be printed on a regular basis, there was a group of printers in the Republic who were attracted by the prospect of making financial gains. One way to increase their profit margin was by securing a so-called "printing privilege" from the local authorities. A printing privilege provided the exclusive rights for a limited time (generally around 8 years) to print a book for the Dutch market. ${ }^{20}$ Regularly issued for the printing of catechisms and schoolbooks written in Dutch, the Republican authorities did not issue many printing privileges for the production of works in Latin. In 1581, for example, the schoolmaster Cornelius Schonaeus (1540-1611) had tried in vain to obtain a privilege for a Latin grammar book, which would prevent instruction "from any other grammar book in the province of Holland." ${ }^{21}$ His request was denied, and the States of Holland opted to give a reward instead. The same year, the famous printer Christophe Plantin (ca. 1520-1589) made another attempt to obtain a printing privilege for a grammar book by Cornelius Valerius (1512-1578), a former professor of Latin at the famed Collegium Trilingue in Leuven (Molhuysen 1913, 18 (27 $7^{\text {th }}$ of April 1581). Although supported by the Leiden University Senate, Plantin's attempt to claim the exclusive rights to the Latin grammar book were similarly unsuccessful. The book by Valerius, first published in 1567, would indeed never be printed in the Republic, but in Antwerp, in 1583, under the earlier privilege that had been issued to Plantin by the Spanish Habsburg authorities in 1566 for a set of books once written by the Leuven Professor for the instruction of the youth:

Grammaticarum institutionum libri quatuor.

Tabula summam artis Rhetorica complectens etc.

\footnotetext{
${ }^{19}$ The short overview by Frijhoff is obviously far from complete; a full transcription of the Order can be found in (Kuiper 1958, 5-25).

${ }^{20}$ Printing privileges were mainly issued by the (inter)provincial authorities in the Dutch Republic, not by the cities. In addition to sanctions against copying, they often contained a clause that prohibited the import of printed materials from abroad. The first printing privileges issued independently by the Dutch authorities date from the 1580s; they were issued for books as well as for other printed materials, such as globes and copper engravings. On the history of printing privileges in the Dutch Republic, see (Hoftijzer 1993; Schriks 2015; Buning 2019; Orenstein 2006).

${ }^{21}$ (Kuiper 1958, 39-40): "van dat geene andere grammatica binnen Holland geleert soude mogen worden,"18th of March 1581. Schonaeus was the rector of the Latin School in Haarlem; the book was commissioned by the States of Holland, being part of the first political interference in the Dutch educational program by Prince William of Orange, who consulted a commission that included high-level scholars such as Douza, Lipsius, and Donellus. Schonaeus eventually obtained fifty guilders instead of a printing privilege.
} 
Tabulae totius Dialectices etc.

De sphaera \& primis astronomia rudimentis libellus.

Physicae, sue de natua philosophia institutio etc. ${ }^{22}$

In the wake of the Council of Trent (1545-1563), the Spanish Habsburg authorities had clearly chosen to privilege a strong and uniform teaching program in preparation for the Faculty of the Arts. The School Order, as we shall see, was in many ways an attempt to keep up with the educational program as it was implemented in Leuven and elsewhere.

In contrast to what happened in Leuven, however, the Dutch authorities chose not to issue any printing privilege for the books produced in the framework of the School Order. The magistrate of Leiden had initially pushed in the States of Holland for a privilege on "the first Edition of the Books of the School Order, revised and addressed by the Deputies of the Senate of the University, in Leyden, so that the first Copies may be printed perfectly." 23 Yet most members of the Assembly abhorred the idea of a Leiden privilege and it was soon decided that printing the books in the School Order "should remain free" to all. ${ }^{24}$ Nonetheless, Burgersdijk initially managed somehow to obtain a printing privilege for his compendium on logic (the Institvtionvm logicarvm), which inevitably led to problems when he presented the finished book in the Assembly on the $23^{\text {rd }}$ of September 1625. At that point, the authorities decided "that the privilege will not have force, and [instead] to honor him [=Burgersdijk] with a hundred and fifty guilders for his trouble and Dedication." 25 After strong objections by the author, the States reconsidered its decision one week

\footnotetext{
${ }^{22}$ The example comes from (Valerius 1583, A-IV) but can be found in any of the books listed here. See also (Imhof 2014, 702-03). De sphaera by Valerius, for that matter, again followed closely the order used by Sacrobosco.

${ }^{23}$ (Koninklijke Bibliotheek, KW 402 A 31, 607): “...om den eersten Druk van de Boeken van de Schoolordre, by de Gedeputeerden van den Senaat van de Universiteyt gerevideert ende geaddresseert, te moogen doen doen binnen Leyden, op dat de eerste Exemplaren perfect moogen werden gedrukt...," $20^{\text {th }}$ of December 1625. The source material as well as translations of the "Resolutions concerning the Dutch School Order" can be found online at (Bently and Kretschmer 2017). Note that a couple of months later, the Leiden authorities again probed "whether one had to grant the Professors (who corrected the Books) a privilege for some years to have the Books printed at Leyden, so that these would be printed well and correctly for the first journey" (of men de Professoren (de Boeken gecorrigeert hebbende) soude moogen toestaan Octroy voor eenige jaaren, om de Boeken tot Leyden te doen drukken, op dat se wel en correct souden moogen worden gedrukt voor de eerste reyse). Koninklijke Bibliotheek, KW 402 A 31, 663 ( $8^{\text {th }}$ of April 1626). The Provincial Assembly again decided against it.

${ }^{24}$ (Koninklijke Bibliotheek, KW 402 A 31, 607): “...het selve moeten aan alle de Leeden vry gelaaten werden," $20^{\text {th }}$ of December 1625. Translation and transcription available online at (Bently and Kretschmer 2017). It is remarkable that all of the first editions were nevertheless printed in Leiden, and that also later on, Leiden printers kept a privileged position in practice.

${ }^{25}$ (Koninklijke Bibliotheek, KW 402 A 31, 751): “...dat het Octroy van geen kragt en sal weesen, ende dat men hem voor de moeyte en Dedicatie vereeren sal met honderd vyftig guldens," $23^{\text {rd }}-24^{\text {th }}$ of September 1626. Translation and transcription available online at (Bently and Kretschmer 2017).
} 
later, agreeing "that the aforesaid Privilege will serve him from now on for another year in order to get rid of his Copies at a price deemed appropriate by the Delegates States." ${ }^{26}$ Burgersdijk was forbidden, however, to print any additional copies mentioning the existence of a printing privilege.$^{27}$ It was, indeed, without any privilege that Bonaventura Elzevir (1583-1652) and Abraham Elzevir (1592-1652), the printers to the University of Leiden, ${ }^{28}$ one year later marketed the octavo edition of:

Sphaera Johannis de Sacrobosco, Decreto Illustr. \& Potent. DD. Ordinum Hollandiae \& West-Frisiae, in usum scholarum ejusdem provinciae, sic recensita, ut \& Latinitas, \& methodus emendata sit, multaque addita, quae ad huius doctrinae illustrationem requirebantur. Operam \& studio Franconis Burgersdicii. Lugduni Batavorum, Ex Officina Bonaventurae \& Abrahami Elzevir. Academiae Typogr. 1626 (Burgersdijk and de Sacrobosco 1626).

The professors involved in the editing and production of schoolbooks that had become mandatory under the School Order would eventually obtain a total of 2000 guilders for their collective efforts. ${ }^{29}$ Alas, we do not know the exact share of this that Burgersdijk received. What we do know, based on a declaration signed by Burgersdijk upon finishing his project, is that the 1626 edition of De sphaera had a first print run of 600 exemplars, which were sent to twenty different cities in the province of Holland; the biggest school had to purchase ninety-six exemplars and the smallest school six (Kuiper 1958, 86). ${ }^{30}$ Apparently, the Hoorn school master Jacobus Hovius managed somehow to get the schoolbooks for his students for free (Abels 2002, 409), but the rest of books were sold for exactly one stuiver and thirteen penningen per book. ${ }^{31}$ Considering the large numbers of books that were sent to the schools, we may assume that the books were used by students individually in class and passed on from year to year (i.e. they remained in the school).

\footnotetext{
${ }^{26}$ (Koninklijke Bibliotheek, KW 402 A 31, 758): “...om middelertydt syn exemplaren quyt te maaken, ten pryse als de HH. Gecomm. Raden sullen goedvinden ende geen meer moogen doen drucken," $1^{\text {st }}$ of October 1626. Translation and transcription available online at (Bently and Kretschmer 2017).

${ }^{27}$ That printers did not always adhere to the state regulations can be deduced from the fact that, in 1645, an abridged version of Burgersdijk's Logic was still printed with an indication of the 1626 privilege issued by the States General (Burgersdijk 1645). The original printing privilege had by then long lost its legal validity. On the value and meaning of these expired printing privileges, see (Buning, 2019).

${ }^{28}$ On the Elzeviers, see (Willems 1880; Dongelmans et al. 2001).

${ }^{29}$ (Koninklijke Bibliotheek, KW 402 A 31, 780-81), 19 $9^{\text {th }}$ of November 1626. Available online at (Bently and Kretschmer 2017).

${ }^{30}$ The total printing cost of the project was 4604 guilders and fourteen stuivers. Although we lack the exact numbers, the size of the Latin school student body was considerable in the seventeenth century Dutch Republic. It has been reported that, at some point, 2200 students attended a Latin school in Amsterdam (Fortgens 1958, 31). In that light, 600 copies of De sphaera was not necessarily such a large number.

${ }^{31}$ A guilder was worth twenty stuivers; one stuiver equaled sixteen penningen.
} 


\section{Situating De sphaera}

To fully appreciate the status of De sphaera in the educational program of the School Order, it is necessary to say a few words more about the educational system in the Dutch Republic. That system was divided into several phases. The youth first learned to read and write, as well as the fundamentals of the Heidelberger catechism, in so-called "Dutch Schools" (Nederduytsche scholen), or occasionally in "French Schools" (Franse scholen), where they were taught a few words of French and where usually some more attention was given to mathematics and geography. ${ }^{32}$ Youngsters attended these schools (with a lot of variation) between the age of five and twelve, after which most of them dropped out to take up a trade or a craft. Only some continued to follow courses on specific topics in private or evening schools, and only a select group of boys would continue to attend a Latin school that prepared them for university education. ${ }^{33}$ Only at the Latin schools was education carried out in groups, in contrast to the other school types, where teaching was done on an individual basis.

The Latin schools were subdivided into six classes, of which the highest class (class 1) was sometimes split into two divisions. For most pupils, the lowest division was the normal terminus of their education. But sometimes a select group of pupils formed a second division in which more attention was given to topics that were part of the curriculum at the University Faculty of the Arts. It was exclusively in these upper divisions that fragments of De sphaera were read. ${ }^{34}$ In fact, the School Order had been quite precise about when to read the textbook by Sacrobosco, namely on any day except Wednesday and Saturday:

In the highest division, when such a division exists in accordance with local circumstances and tradition, the beginnings of higher philosophy will be taught. And to this end will be taught: The Physics by Magirus, the Ethics by Walleus, the Arithmetic of Gemma Frisius, and the Sphaera by Sacobosco, with as much improvement of the Latin as possible. Furthermore, for the General History of Rome and the Outside World, Plorus and Justinus. Moreover, from Mela or Dodonaeus, and from 6 or 7 of the most important maps of Ortelius, the situation of the known parts of the world. ${ }^{35}$

\footnotetext{
${ }^{32}$ There were many variations and even crossovers possible between French and Dutch Schools. Some major cities also had Grote Scholen, a remainder of the Middle Ages, which combined primary and secondary education. The Grote Scholen were paid for by the urban governments, however, and thus the influence of the Church was limited. This paragraph is based on (Booy 1980, 23-50).

${ }^{33}$ For the history of the Latin schools see (Bot 1965; Fortgens 1958; Bastiaanse and Evers 1986; Bastiaanse et al. 1985; Emmius 1951; Witsenburg and Van der Noordaa 1988).

${ }^{34}$ Such classes seem to have flourished mainly in cities where at some point either an Athenaeum Illustre (Deventer 1630, Amsterdam 1632, Breda 1646, Rotterdam 1681) or a university would be founded (Leiden 1575, Franeker 1585, Groningen 1614, Utrecht 1636, Hardewijk 1648, Nijmegen $1655)$.

${ }^{35}$ (Kuiper 1958, 20): "In superiori ordine, ubi is pro loci conditione admitti solet, initia solidioris Philosophiae traduntur. Atque hic docebitur Physica Magiri, Ethica Wallaei, Arithmetica Gemmae Frisii, Sphaerica Sacrobosci, Latinitate ubi poterit emendata. Item propter Universatem Historiam Romanam et Externam Florus et Justinus. Item ex Mela aut Dodonaeo, et sex septem tabulis praecipuis Ortelii, docebitur situs nobilium partium orbis terrarium."
} 
The authors of the Order envisioned a comprehensive program, in which the pupils in the highest class would gain a broad overview of geography, astronomy, ethics, and natural philosophy. The next section will explore in which ways the Dutch were influenced by earlier initiatives of the Jesuits in this respect.

\section{Burgersdijk's Edition of De sphaera}

The 1625 School Order had not been the first attempt to organize the educational system in the independent Northern Netherlands. The province of Friesland had introduced a first School Order in 1588, and similar directives are known in Zeeland (1590) (Cau et al. 1664, 2:column 2207-08) and Gouda (1593) (Abels 2002, 409). Moreover, there were many urban regulations regarding the Latin Schools (an inventory of all Latin schools of the Republic in 1650 shows that ninety-two towns had a Latin school (Frijhoff and Spies 2004, 245)). These policy measures were a local affair, but also played an important role within an international framework of continuous ideological warfare. Accordingly, the Holland School Order of 1625 should be seen as a concrete response to Jesuit efforts to streamline the educational program, including the 1566 Leuven initiative mentioned earlier, or the Ratio Studiorum of $1599 .{ }^{36}$ The Curators of Leiden University emphasized this aspect in their 1624 guidance letter to the Senate, where they unambiguously stated that the School Order was needed:

Just as similar orders unifying the class schedules have been implemented with enormous success by the Enemies of our Religion in the schools of the Jesuits, who, much to our disadvantage and prejudice, have managed that way to direct and prepare their youth much better for the further understanding of the higher disciplines, which are afterwards studied in the universities. ${ }^{37}$

The Holland School Order was thus part of a broader process to gain control over the educational system in an attempt to establish the Dutch Republic as a Calvinist state. Other elements in that process included the appointment of school masters who, from 1619 onwards, were obliged to sign a confession that they supported the

\footnotetext{
${ }^{36}$ I am not elaborating here on the various efforts made in the Catholic world to gain control over the educational system. For an excellent analysis on the impact of the Ratio Studiorum, with a focus on mathematics and France, see (Romano 1999).

${ }^{37}$ (Kuiper 1958, 49-50): "Gelyck deselffde eenparige ordre van lessen met sonderlinge goet succes werdt gepractiseert by de Vyanden onser Religie in alle scholen der Jesuyten, die, tot onse groote affbreucke ende naerdeel, hare jeucht inde so eerste beginselen met dusdanige eenparige ordre veel beter aenleyden ende bequaem maecken tot het vordre begryp van hoogere disciplinen, die daernaer in de Universiteyten werden geleert." In 1624, the Curators had still pushed for a "national" Order, but due to practical considerations the Senate later decided to first realize a provincial order in the hope that other provinces would follow the example set by Holland.
} 
Canons of Dort (Kuiper 1958, 51) as well as the ban on Catholic teaching to counter the spread of "popery superstitions" (States of Holland 1589)..$^{38}$

Amidst these various power games to claim hegemony in the religious sphere, one also finds a reference to De sphaera by Sacrobosco-a teaching book, originally written around 1230, that had served for several centuries to instruct the youth of the Western Latin world in the first principles of astronomy. ${ }^{39}$ Especially with the breaking apart of the Christian world in sixteenth-century Europe, several editions of De sphaera had come to compete fiercely with one another. The Lutheran reformer Philipp Melanchthon (1497-1560), for instance, had used the text of Sacrobosco to formulate a panegyric on astronomy that "taught about Providence" (Kusukawa 1995, 129) (Chap. 10), whereas the Jesuit mathematician Christopher Clavius (1538-1612) used De sphaera from 1570 onwards as book of loci containing the Summa of his cosmological insights. It was particularly in the paratext and the commentaries that De sphaera concealed particular worldviews. The 1626 edition by Burgersdijk was no exception in that respect.

Burgersdijk's version of De sphaera was preceded by a short preface (see Appendix). There, the author explained that the representatives in the States of Holland had made it his assignment to purify the text by Sacrobosco from its "barbaric" (barbariem) Latin, making the textbook perspicuous and easy to understand. The Leiden professor clearly stated that his edition of De sphaera had been chiefly inspired by the "highly learned" (doctissimus) work of Christophorus Clavius, to which he had added some of Peuerbach's Theorica novae planetarum (actually, Clavius had done the same). In contrast to his Jesuit counterpart, however, Burgersdijk did not include any excursions on mathematical demonstrations, since this would go beyond the understanding of his readers. His aim was primarily to provide an effective textbook "from which adolescents could learn the first principles of Astronomy, later to be studied more fully and accurately in the Academy." 40

The unconcealed reference to a famous Jesuit mathematician in a book by a Calvinist Aristotelian in the Dutch Republic is, at first sight, remarkable. First published in 1570, Clavius's work had been privileged by Pope Pius V (1504-1572) "to the common benefit of all the scholarly community as well as his Jesuit comrades (sociorum)," and it had become a standard work in Jesuit defense against the Copernican worldview (Clavius and de Sacrobosco 1570, A1v). ${ }^{41}$ Clavius had com-

\footnotetext{
${ }^{38}$ The placard against printing seditious religious literature, first issued by the States of Holland on $20^{\text {th }}$ of December 1581, was later renewed in various forms and variations. As an introduction to censorship in the Republic, see (Weekhout 1998).

${ }^{39}$ For a first introduction to (the commentary tradition on) De sphaera, see (Hamel 2014; Pedersen 1985; Thorndike 1949; Valleriani 2017).

${ }^{40}$ (Burgersdijk and de Sacrobosco 1626, sig. a1-a2v): "ut ex eam adolescentes prima Astronomiae principia deliberarent, quam in Academiam deinde discerent plenius accuratiusque." See Appendix. 41 "ad communem omnium studiosorum vtilitatem suis sociorumque...." Note that the printer Victorius Helianus (Vittorio Eliano) obtained a highly interesting privilege for a set of books to promote the Jesuit production of knowledge. Eliano was a converted Jew, who specialized as a censor of Hebrew texts (Casetti 1993).
} 
plemented each fragment of the text by Sacrobosco with an extensive commentary, which had resulted in a hefty book with an index on chapters, persons, and topics (the first edition had consisted of no less than 506 folio pages). The Jesuit Father then continued to update his book in the seventeen subsequent editions that followed in the years 1581-1611, which represented something of a highpoint in the early modern commentary tradition on De sphaera..$^{42}$ Yet another important strand in that tradition were the annotations by French humanist Élie Vinet (1509-1587), first published in 1556, and later reprinted on almost a yearly basis. ${ }^{43}$ Over time, Vinet's commentary was complemented by other commentaries, and it was often printed together with additional compendia; yet it remained the basis for the proper understanding of Sacrobosco's text in the sixteenth and seventeenth centuries. As an illustration, a 1573 edition published by the Antwerp printer Jean Bellère (1526-1595) included, in addition to a version of De sphaera annotated by Vinet and Franciscus Junctinus (Francesco Giuntini, 1523-1590), Sacrobosco's Computus ecclesiaticus as well as his Alogarismus, a compendium to De sphaera by Ioannes Pierius Valerianus (Pierio Valeriano, 1477-1558), and the commentary by Pedro Nuñes (1502-1578) on the climate zones (Sacrobosco et al. 1573). The idea to print De sphaera together with the Computus ecclesiasticus had first come from Melanchton and Georg Joachim Rheticus (1514-1574), whose so-called Wittenberg editions might be identified as a third strand in the early modern commentary tradition on Sacrobosco's text (Rosen 1974, 245; Westman 1975) (Chap. 9). ${ }^{44}$ Indeed, just as interesting as Burgersdijk's open reference to Clavius in the Leiden edition is his omission of any references to other editions of De sphaera that circulated on the market at the time.

In comparison to those other editions, the version put out by the printers of Leiden University was rather short. After 120 pages of text on the sphere followed a simple table of contents without any index on name or topic. The aim was to deliver a book without curlicues. To that end, Sacrobosco's non-humanist Latin had to be "improved" (emendata) as well. ${ }^{45}$ Burgersdijk faithfully followed the original order, yet rewrote De sphaera in such a rigorous manner that some scholars have come to argue that it essentially resulted in a new text (Hamel 2014, 44). It suffices to compare the opening words in the original with the retranslation to illustrate the radicalism of Burgersdijk's editing methods:

\footnotetext{
${ }^{42}$ Carefully revised reprints of the work appeared in Rome (1581 and 1585), Venice (1591), Lyon (1592, 1593 and 1594), Venice (1596 and 1601), Rome (1606), San Crispino (1608), and finally in Mains (1611-1612).

${ }^{43}$ The commentary by Vinet was mainly printed in Paris but also in other cities, including Lyon, Koln, Venice, and Antwerp (Valleriani 2017). Database accessible through: https://sphaera.mpiwgberlin.mpg.de/. Accessed June 2019.

${ }^{44}$ I would like to thank Matteo Valleriani for pointing out that there was a long tradition of combining the Computus and De sphaera together in manuscript form; the idea to do so in print marked essentially a return to an older tradition.

${ }^{45}$ Citation taken from the School Order, see (Kuiper 1958).
} 
Sphaera igitur ab Euclide sic describitur: Spaera est transitus circunferentiae dimidii circuli quae (fixa diametra) eousque circunducitur, qousque ad locum suum redeat. id est: Shaera est tale rotundum \& solidum, quod describitur ab arcu semicirculi circunducto. (de Sacrobosco et al. 1574, 6)

Except for some minor issues of orthography, all of the earlier editions had made use of exactly the same wording. Instead, Burgersdijk rendered this little fragment into:

Sphaera, defieniente Euclide, est figura, quae, converso circa diametrum quiescentem semicirulo, \& in eundem rursus locum restituto, à quo coeperat moveri, continetur. lib. II. d. 14 hoc est, Spheara est rotundum, quod semicirculo circumducto describitur. (Burgersdijk and de Sacrobosco 1626, 6) ${ }^{46}$

The brief example gives an impression of how Burgersdijk went about rewriting the original Latin without, however, essentially changing the original design of the text. ${ }^{47}$

This is not to say that Burgersdijk did not make numerous subtle changes. In doing so, he was-as he had indicated in the preface-primarily inspired by Clavius's extensive commentaries, merging them integrally, albeit in a highly abbreviated form, with the original text by Sacrobosco. His "method" (methodo) becomes immediately apparent when comparing his text to the earlier versions of his Jesuit counterpart. ${ }^{48}$ To illustrate, Clavius had made an extensive twenty-two-page "commentary" (commentarius) in his 1570 edition on Sacrobosco's chapter on the size of the earth, listing various alternative opinions and calculations, beginning from Aristotle (384-322 BCE) and Alfarganus (al-Farghani) (ca. 805-870) and extending to more recent authors like Jean François Fernel (1497-1558) (Clavius and de Sacrobosco 1570, 265-67). ${ }^{49}$ In other commentaries, such as those by Vinet and Giuntini, these numbers could not be found. Yet Burgersdijk listed the exact same numbers as Clavius in a throwaway sentence (Burgersdijk and de Sacrobosco 1626, 27-28), omitting a direct reference to his source, or to any tables and mathematical demonstrations that could be found in the work of his Jesuit predecessor.

In many ways, Burgersdijk's text reads as a highly condensed abridgement of Clavius's masterpiece. The Leiden Aristotelian proceeded freely in summarizing his predecessor's insights, occasionally merging together different comments that had been presented separately (such as Clavius's expositions on the composition and on centrality of the earth). ${ }^{50}$ Every now and then, Burgersdijk incorporated information

\footnotetext{
${ }^{46}$ The reference to book 11 in Euclid could be found in the editions annotated by Vinet, but not in the works of Clavius; although Burgersdijk could have taken this reference from anywhere, it seems likely that he was aware of the reference in Vinet's works.

${ }^{47}$ It should be noted that Burgersdijk did divide the four sections of the original text into four actual parts (partes), each with individual chapters, instead of using four chapters with unnumbered subheadings, as had been customary. Yet he did not change the order of the text.

${ }^{48}$ The use of methodo comes from Burgersdijk's letter to the reader (Burgersdijk and de Sacrobosco 1626, sig. a2). See Appendix.

${ }^{49}$ The entire chapter De ambitu terrae by Clavius on the size of the earth runs from page 250 to 272. Like many other commentaries, it was copied into later editions.

${ }^{50}$ Chapter VII in Burgersdijk (Burgersdijk and de Sacrobosco 1626, 23-25) provided a summary of (Clavius and de Sacrobosco 1570, 151-74) and (Clavius and de Sacrobosco 1570, 175-244).
} 
from other textbooks as well. ${ }^{51}$ But at all times he meticulously followed the argumentation and sequential layout of his Jesuit example. Clavius, for example, had divided the original chapter in Sacrobosco on the meridian and the horizon into two different chapters, each with its own commentary. ${ }^{52}$ Burgersdijk did exactly the same, whereas such a division cannot be found in any edition based on the comments by Vinet and Giuntini. ${ }^{53}$ Following the Jesuit's lead, Burgersdijk also wrote about the various movements in the eighth, ninth, and tenth spheres. There was no doubt that this motion "had been unknown to Aristotle" and his predecessors but confirmed by recent astronomical observations (Chaps. 5 and 8). ${ }^{54}$ And yet the "earth was immobile" at the center of the universe (Burgersdijk and de Sacrobosco $1626,26){ }^{55}$ In this respect too, Burgersdijk closely followed Clavius, defending geocentrism at a time when Galileo Galilei's (1564-1642) discoveries were commonly known and Copernican cosmology widely discussed. ${ }^{56}$

The question then, perhaps, is why the Dutch authorities considered the text by Clavius particularly appropriate to shape the minds of young Dutch youth. ${ }^{57}$ James Lattis has listed in this connection a number of points characterizing what he called Clavius's “Orthodox Cosmology" (Lattis 1994, 65-85). These points include, among others, (1) the reconciliation of the Ptolemaic planetary system with Aristotelian physics, (2) the consensus on the overall size of the cosmos, and

\footnotetext{
${ }^{51}$ Burgersdijk listed, for example, exact numbers for the cycles of the planets (Burgersdijk and de Sacrobosco 1626, 13), whereas these had only been indicated by approximation in Clavius (Clavius and de Sacrobosco 1570, 97; Clavius and de Sacrobosco 1611, 30). One possible source is (Simi 1555,70 ), yet the same numbers can be found in other handbooks as well.

${ }^{52}$ Clavius's separate treatment of the meridians had become necessary to include the enormous amount of new information that had become available in the wake of the European voyages of discovery. The chapters on the meridian and the horizon start at pp. 338 and 361, respectively. The influence of new voyages returned in various contexts. Vinet, too, had argued for example that the disagreement on the inhabitability of the tropics was "held by experience" (habetur ab experientia), identifying Columbus's 1491 journey as the major transition point (Bellère 1573, 43). Burgersdijk did exactly the same, highlighting how recent experience had shown that various parts of the world were indeed inhabitable (Burgersdijk and de Sacrobosco 1626, 51).

${ }^{53}$ Burgersdijk's division of Sacrobosco's original chapter on the meridian and the horizon conveys by comparing Burgersdijk's chapter V (Burgersdijk and de Sacrobosco 1626, 41-46) and chapter VI (Burgersdijk and de Sacrobosco 1626, 42-47) with, for instance, (Sacrobosco, Vinet, and Giuntini 1573, 35).

${ }^{54}$ (Burgersdijk and de Sacrobosco 1626, 12): "Hic motus Aristoteli, aliisque ante Aristotelem Philosophis \& Astrologis, fuit incognitus." Burgersdijk also used the example of Timocharis here, just as Clavius had done (Clavius and de Sacrobosco 1570, 81).

55 "Terram est immobilem." Compare with (Clavius and de Sacrobosco 1611, 106).

${ }^{56}$ On the comets of 1577 and 1618 and the so-called "decline of the Aristotelian worldview" see also (Van Nouhuys 1998). It may be worth noting that, after visiting the astronomer in the Tuscan countryside, the Elzeviers also published Galileo's Discorsi in 1638; a year before they reprinted Burgersdijk's Sphaera (see below in text).

${ }^{57}$ It remains an open question where Burgersdijk got the idea to integrate the text of Clavius with the original text of Sacrobosco. In 1601 and in 1610, a mixture of Vinet and Clavius had been printed in Cologne by the Jesuit Hofbuchdrucker Peter Cholinus (J. de Sacrobosco et al. 1610). Yet Clavius's remarks in that edition had been limited to only to a few short remarks, primarily at the beginning of each of the four main parts. Burgersdijk's notes were much more precise.
} 
(3) the acceptance of the order of planetary spheres according to Ptolemy (ca. 100-ca. 160). ${ }^{58}$ On all of these issues, Burgersdijk clearly followed his Jesuit paragon, using the same examples and the same style of argument, also when speaking for instance of the existence of an immobile empyrean heaven beyond the moving spheres as "a seat of the blessed" (Burgersdijk and de Sacrobosco 1626, 14). As Lattis has argued, this quantitative world picture, where the afterlife had a distinct place, was vital for maintaining a Christian vision of the cosmos (Lattis 1994, 82). ${ }^{59}$ It must have been precisely this aspect that made Clavius's orthodox views so appealing to the Leiden Neo-Aristotelians and their allies.

Yet, in some places, Burgersdijk remained selective in his rendering of Clavius's comments. He copied only the bits and pieces that he considered relevant and strategically eliminated certain specifics. Whereas Clavius, for example, had spoken of the empyrean heaven as a "a happy seat and home of the angels and the blessed," 60 the Leiden professor simply spoke of a "a seat of the blessed." ${ }^{11}$ Hence, in line with his Protestant faith, he placed less emphasis on the existence of angels. And Burgersdijk omitted other, perhaps more important aspects too. He did not mention, for instance, Clavius's ideas of the existence of an eleventh sphere, introduced by the Jesuit author in his reworks from 1593 onwards, to accommodate Copernican precession theory (Lattis 1994, 171; Grant 1994, 318). ${ }^{62}$ The reason for clinging on to earlier ideas on the topic of ten moving spheres was probably not that Burgersdijk lacked access to Clavius's later editions, ${ }^{63}$ but his unwillingness to reject Alfonsine trepidation theory in favor of a model based on Copernican mathematics. ${ }^{64}$

\footnotetext{
${ }^{58}$ The order of planetary spheres is the moon, Mercurius, Venus; then, the Sun, Mars, Jupiter, Saturn, the eight and the ninth sphere, and the primum mobile, beyond which there was only an empyrean heaven. On rival cosmologies, see (Lattis 1994, 73-77; 86-106) (Chap. 5).

${ }^{59}$ On the various opinions regarding the existence of an empyrean heaven, see (Grant 1994, 270-89).

${ }^{60}$ (Clavius and de Sacrobosco 1570, 62; Clavius and de Sacrobosco 1611, 24): "felicem angelorum beatorum sedem ac patriam."

${ }^{61}$ (Burgersdijk and de Sacrobosco 1626, 14): "sedes beatorum."

${ }^{62}$ Clavius added a moving sphere, following the ideas of Giovani Antonio Magini. Adopting "the adapted Copernican scheme for the motions of the fixed stars" probably resulted from his work on the calendar reform (Lattis 1994, 173). Burgersdijk sticks to ten moving spheres; see note 58.

${ }^{63}$ It is extremely difficult to pin down with certainty which edition of Clavius's work Burgersdijk might have used, yet a number of editions can be reasonably excluded; Burgersdijk mentioned Pope Gregory XIII's calendar reform of 1582 (Burgersdijk and de Sacrobosco 1626, 40) using the same terminology and order as in (Clavius and de Sacrobosco 1611, 147). Obviously, the remark on the calendar reform had been absent in editions earlier than 1582. See also (Clavius and de Sacrobosco 1570, 331). Perhaps, a future comparative analysis of the imagery in the various editions can provide an answer to the question of which version Burgersdijk used as a model (the 1585 Rome edition of Clavius was, for instance, very different in terms of imagery and it is hard to imagine that this edition served as an example).
}

${ }^{64}$ Although he did not mention it specifically, Burgersdijk may have objected to the existence of an eleventh sphere on the basis of theological grounds. It is impossible to track down a unique source for Burgersdijk's ideas on this matter. Calvin had rejected the notion of a tenth sphere and remained silent on the existence of a ninth sphere (Kaiser 1988, 83). Perhaps, Burgersdijk was rather inspired in this regard by Coimbra Jesuits (Grant 1994, 321) (Chap. 10), whom he cites approvingly in 
For Burgersdijk, scriptural revelation remained the basis for acquiring knowledge of heavenly motions. It was perhaps for similar reasons that Burgersdijk refrained from mentioning the existence of the telescope, whereas Clavius in his 1611 edition (the final edition completed just before his death) had indicated that the recent discoveries made with an "oblong tube" (tubi...oblongi) required astronomers to rethink how the celestial orbs could be arranged in order to save the phenomena (Clavius and de Sacrobosco 1611, 75). Omitting such particulars, which had the potential to shake up worldviews, allowed Burgersdijk to embrace Clavius's cosmology without thereby endorsing Clavius's “ontologically loaded" physical mathematics (Chap. 6). ${ }^{65}$

Whereas Burgersdijk's edition of De sphaera was primarily inspired by Clavius in terms of content, it included elements from the 1573 Antwerp edition published by Bellère in terms of imagery (which in turn had been based on the so-called 1538 Wittenberg edition) (Chap. 8). The illustrations to the text were interlaced at similar locations. ${ }^{66}$ The volvelle in Burgersdijk, for instance, came at the end of chapter one of the third part (on the rise of zodiacal signs), just as in the Antwerp edition; the tool was not to be found in Clavius (Sacrobosco et al. 1573, 48; Burgersdijk and de Sacrobosco 1626, 56). ${ }^{67}$ The design for the illustration of the five climate zones (Burgersdijk and de Sacrobosco 1626, 51) was clearly imitative of the Antwerp edition (Sacrobosco, Vinet, and Giuntini 1573, 43), whereas the layout was entirely different in the edition prepared by Clavius (Clavius and de Sacrobosco 1611, 187). ${ }^{68}$ A set of images in the chapter on "natural and civil day" (Burgersdijk and de Sacrobosco 1626, 62-89) was again inspired by Bellère, and absent in Clavius. Yet elsewhere, Burgersdijk freely copied visual elements from Clavius's work as well. For instance, an illustration supporting the notion of the roundness of the earth (Burgersdijk and de Sacrobosco 1626, 19) was bluntly plagiarized from Clavius (Clavius and de Sacrobosco 1611, 20; Clavius and de Sacrobosco 1570, 143) and absent in Bellère. The table on different climates around the world (Burgersdijk and de Sacrobosco 1626, 88-95), the only table in Burgersdijk's work, was directly copied from Clavius (Clavius and de Sacrobosco 1570, 480-90; Clavius and de Sacrobosco 1611, 288-89) and was not to be found in that form in Bellère either.

other works as well, or by the work of Jean Bodin, who was widely read in the Republic, and who argued explicitly against the eleventh sphere in his Universae Naturae Theatrum, making extensive references to theological interpretations of the crystalline sphere (Bodin 1596 in (Stimson 1917, 211-12).

${ }^{65}$ I would like to thank Peter Barker for his comments and suggestions on the issue of Burgersdijk's approach concerning Clavius's cosmology. On Burgersdijk's gradual change of view over time with regard to new cosmologies, primarily reflected in his Collegium physicum (1632), see (Vermij 2002, 132-33). The change did not reflect in his booklet on De sphaera.

${ }^{66}$ On illustrations of De sphaera, see (Crowther and Barker 2013; Gingerich 1999; Hamel 2014, 23-49).

${ }^{67}$ Moving parts were first introduced by Joseph Klug in the Wittenberg edition of 1538 (Gingerich 1999, 215). Alas, we do not know who made the engravings, or who was responsible for the editorial decisions concerning illustrations in Leiden.

${ }^{68}$ The exact same illustration can be found in other Antwerp editions published by Bellère as well. For example, in (Appianus 1584, 11). 
In short, Burgersdijk freely proceeded to mix and match illustrations as it best suited him to support and clarify his ideas.

All the same, Burgersdijk's edition made use of considerably less imagery than any of the previous editions. There were, for instance, no additional illustrations for geometrical explanations, like in Clavius's editions, nor was there any place for ornamental imagery. Instead, the thirty-six images in Burgersdijk's edition were newly engraved, in the course of which well-known images got a touch of the Dutch. Two warriors depicted under a sphere were, for example, decked out with a hat typical of Dutch traditional clothing (Figs. 11.1, 11.2 and 11.3) ${ }^{69}$ Elsewhere, a building was made to resemble a Dutch church (Figs. 11.4 and 11.5). ${ }^{70}$ Thus, the work of Sacrobosco was not just adapted to the Dutch market but fashioned to strengthen the sense of Dutch distinctness as well.

The text of De sphaera was never translated into Dutch (i.e. nor Burgersdijk's version, nor any other version). This is somewhat remarkable for a Latin school book, and for the fact that other works by Burgersdijk did appear in translation. ${ }^{71}$ Yet for those who were interested in learning something about astronomy, there were numerous alternatives on the market. Of particular importance was, for instance, the work of Adriaan Metius (1581-1635), who taught in Dutch at the University of Franeker on various topics that were of interest to navigators, engineers, and surveyors. ${ }^{72}$ His 1614 bestseller Institutiones astronomicae et Geographicae (Metius 1614) — despite its title entirely written in Dutch—was a practical textbook on cosmography connecting the theory of the sphere with geography and cartography; it clearly included elements of Sacrobosco, but went much further than his predecessor by including elements of arithmetic and geometry. ${ }^{73}$ And there were other booklets available too, such as the practical guide to the use of globes issued by the

\footnotetext{
${ }^{69}$ On this illustration, see also (Crowther and Barker 2013, 453).

${ }^{70}$ On this illustration, see also (Gingerich 1999, 217-19; Hamel 2014, 39). Notice also the topgallant sail, only present in the Dutch edition.

${ }^{71}$ The other works by Burgersdijk (Institutio physica, 1648; Idea philosophiae naturalis, 1648; Logica practica, 1648, Institutio metaphysica, 1649) were translated by Allardus Lodewijk Kok, who translated Vossius's textbook Elementa rhetorica (Amsterdam, 1648) as well.

${ }^{72}$ The Frisian example was followed in Leiden with the establishment of the Duytsche Mathematique, a mathematical school associated to the University where teaching was carried out in Dutch. For more background, see (Dijksterhuis 2017; Dijkstra 2012).

${ }^{73}$ In a way, one could compare the work of the Franeker mathematician with that of Clavius, except that Metius followed a somewhat different order than Clavius had done in his Sacrobosco. He also introduced new information that had become available due to the voyages of discovery (Chap. 8). On the mixing of the Sphaera with cosmography, see also (Chap. 9) and (Valleriani 2017, 438). An interesting detail in this connection is that Metius used a slogan from Ovid, prominently present in Clavius 1570 panegyric on mathematics, as "his" inscription in various alba amicora (Balck 1618; van Wijckel 1635). Felices animae, quibus haec cognoscere primum, Inque domos superas scandere, cura fuit ("Ah happy souls, who first took thought to know I these things and scale the heavenly mansions!" (Ovid 1989, 23). Metius therewith aligned himself with the conviction that astronomy is extremely useful and even necessary to all aspects of life. On this issue, see also (Omodeo 2017).
} 


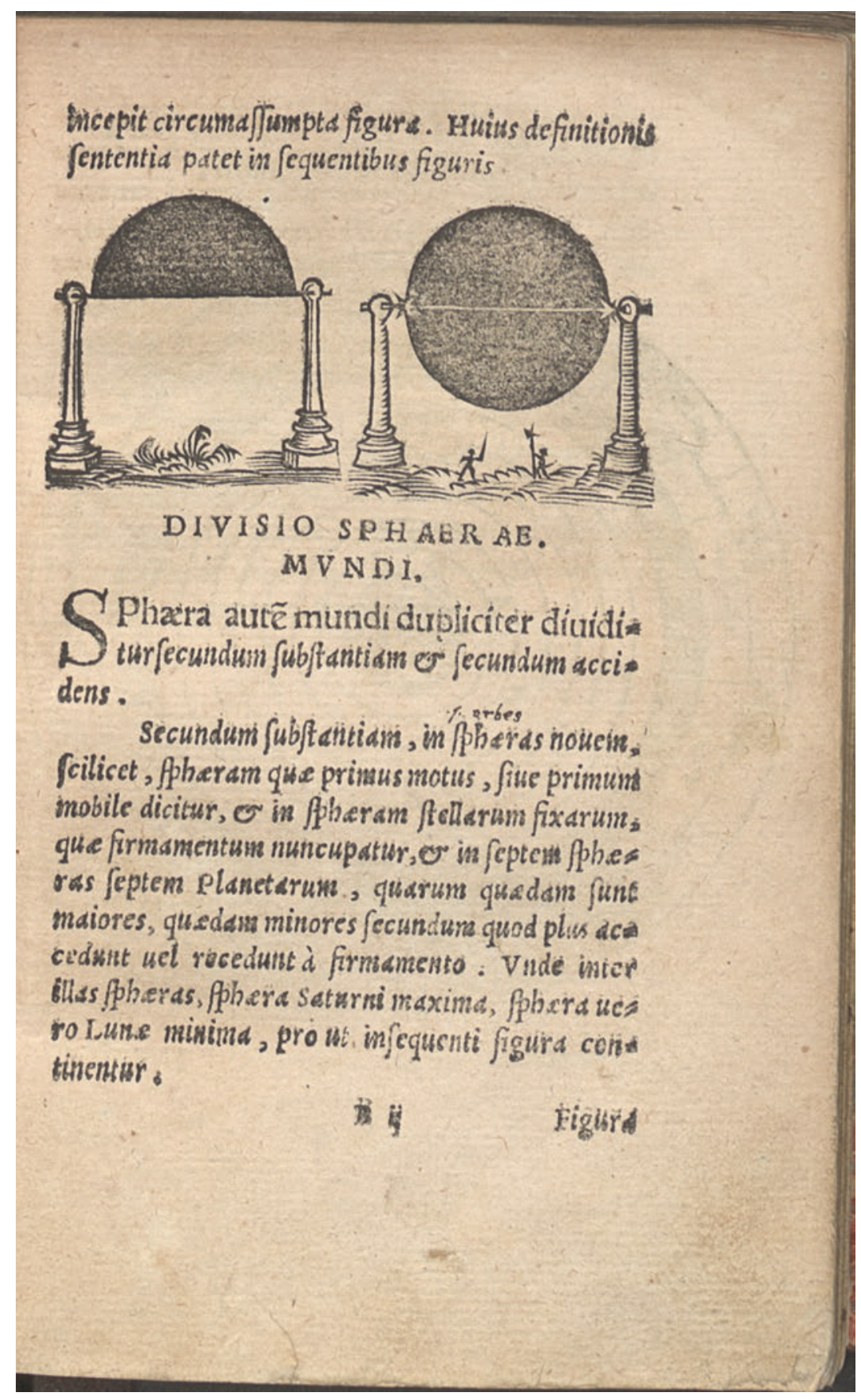

Fig. 11.1 Warriors under a sphere in the Wittenberg edition of 1538. From (de Sacrobosco and Melanchthon 1538, B3r). Bayerische Staatsbibliothek München, Astr.u. 154, urn:nbn:de:bvb:12-bsb00020992-1 
DE SAC. BOS. CA P. I. 3 circunductus femicirculus in idem rur fus redit, vnde copit circun fcribi figura illa. Huitus definitionis fententia ex Jubiectis picturis patere pot est. Quam autem ponit auctor, corruperant Gracorwm Euclides interpretes. Si enim linea in latus fluens defcribit tant ùm /uperfinciem, circunferentia femictrculi curcumacta, defcribet fuperficiem globifolùm, non globum folidum.

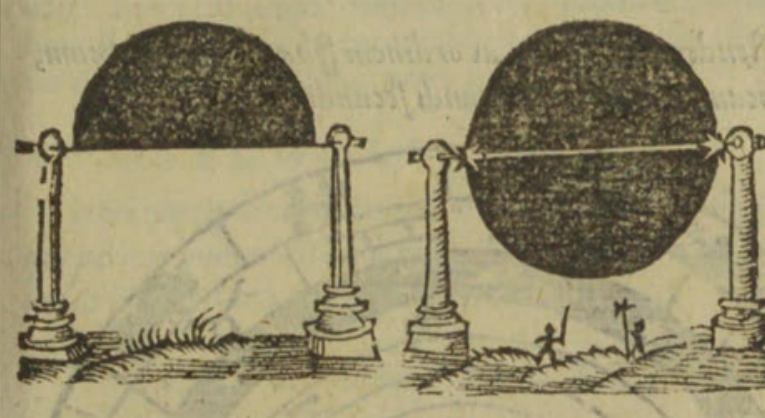

\section{DIVISIO S PHAERAE}

\section{V N D I.}

Shæra autem mundi dupliciter diuiditur, fecundum fubftantiam, \& fecundum accidens. Secundum fubftantiam in fphæras nouem.

\section{SCHOLION VINETI.}

In pheras nouem.) Recentiores Aftrologi decimam Spheram addidersint, propter tertium in octaud ppera animaducrfum motum, quem dixerunt motum trepidationis, of motum accefjus E receffus: de quo Purbachims in Theoricis.

Scilicet fpher exòd none mobile dicitur: mentum nun:\& in $f_{p} h x r a m$ ftellarum fixarum, qux firma celeftes. mentum nuncupatur: \& in feptem fphæras feptem plane- Firmamë-

$$
\text { a } 2 \text { tarum, } t \mathrm{tm} \text {. }
$$
tes infigni ores dine.

Fig. 11.2 The same warriors in the Sphaera emendata issued by the Heirs of Birckmann (Antwerp 1566). From (de Sacrobosco et al. 1566, a2r) 


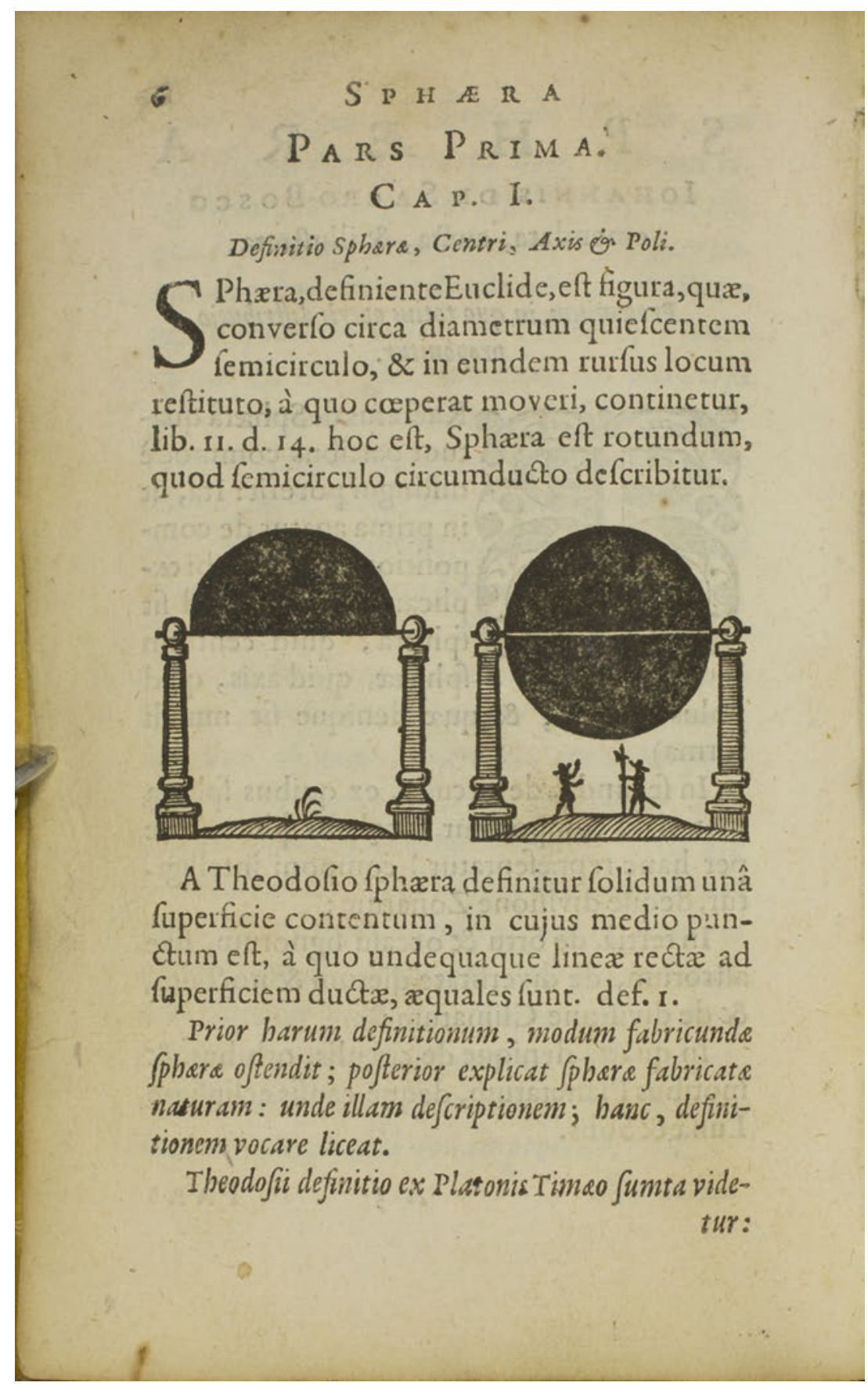

Fig. 11.3 The re-engraved image in the Leiden edition of 1626. From (Burgersdijk and de Sacrobosco 1626, 6). Courtesy of the History of Science Collections, University of Oklahoma Libraries 


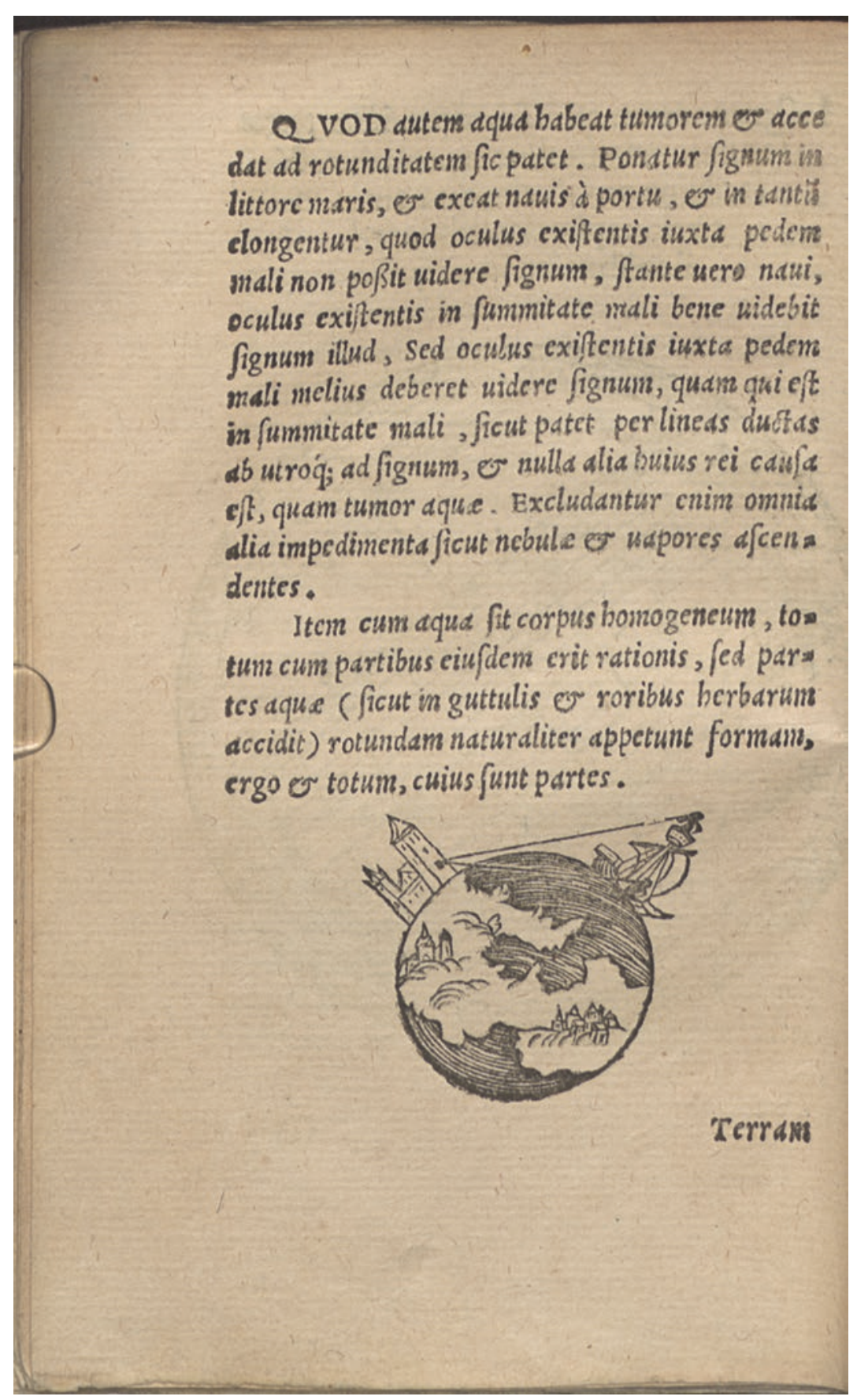

Fig. 11.4 Curvature of the ocean in the Wittenberg edition of 1538. From (de Sacrobosco and Melanchthon 1538, Cv). Bayerische Staatsbibliothek München, Astr.u. 154, urn:nbn:de:bvb:12-bsb00020992-1 
22

\section{$S P$ H AE R A}

habere centrum, quod habet convexa fuperficies terre. Atque id hinc poteft effe manifeltum. Cum navis è portu folvens longiufcule provecta eft, ii, qui in navi juxta calcem mali funt, $\mathrm{fi}_{\mathrm{i}}$ gnum aliquod in littore pofitum, puta turriom, aut pharum, videre non poterunt; quod tamen ab eo confpicietur facillime, qui fummum malum confcenderit. Cum itaq; rationi confentaneum videatur, ut fignum datum non difficilius, vel etiam facilius juxta mali calcem, quam in illius fuprema paree, videri poffit (minus enim à figno diftat, ut in fubjecta figura videre eft) fequitur, nullam caufam hujus rei reddi poffe,pręter aqux tumoré. Nam omnibus aliis impedimentis fublatis, ut funt nebulæ, vapores, \&c. hoc tamen contingit, quod diximus.

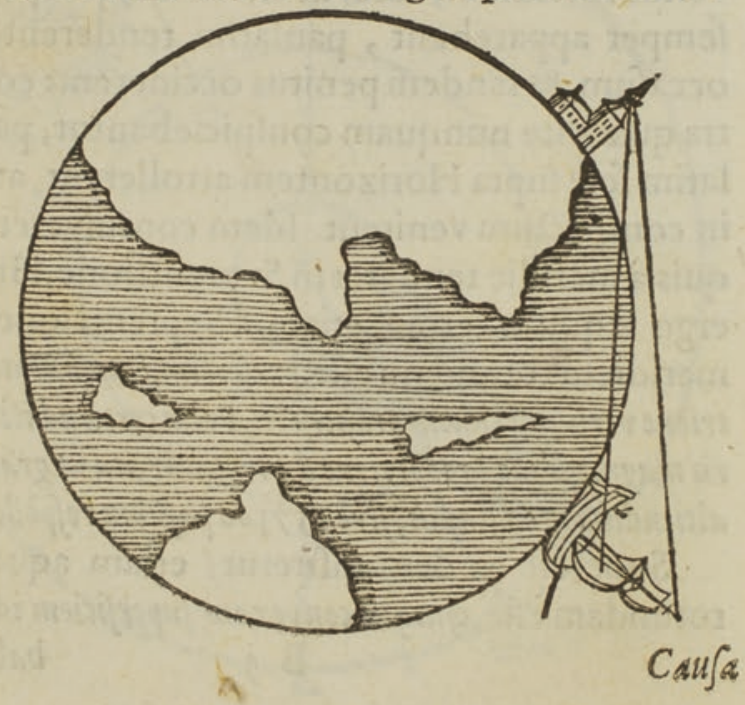

Fig. 11.5 Curvature of the ocean as re-engraved in the 1626 Leiden edition. From (Burgersdijk and de Sacrobosco 1626, 2). Courtesy of the History of Science Collections, University of Oklahoma Libraries 
famed publisher Willem Janszoon Blaeu (1571-1638), who placed the astronomy of Ptolemy and Nicolaus Copernicus (1473-1543) on an equal footing (Tweevovdigh onderwiis van de hemelsche en aerdsche globen was printed in Dutch in 1634, $1638,1647,1666$, and in Latin in 1634, 1652, 1657, 1668, and 1690, under the title Institvtio astronomica).

Despite the existence of alternatives, Sacrobosco's Sphaera could still to be found on Dutch school desks long after Copernican astronomy had changed into an established worldview. In conformity with the School Order, the medieval textbook was, for example, still prescribed in the 1692 statutes of the municipal school in The Hague, where the highest class was to be schooled in "the Logic by Burgersdijk, the Sphaera by Sacrobosco, Florus, The Greek History by Heridianus, Vergilius, Horatius, Juvenalis, etc." ${ }^{\prime \prime}$ Although the statutes did not specify exactly which version of De sphaera the youngsters were supposed to use, it could have very well still have been Burgersdijk's edition; reprints of his 1626 Sphaera followed in 1639, 1647 and 1656 (Burgersdijk and de Sacrobosco 1639, 1647, 1656). We still grope in the dark as regards the timing of these reprints. Perhaps the establishment of new schools in the Generality Lands played a role (compare in this connection the publication dates with the program for the Latin School in "s-Hertogenbosch below). Perhaps the Latin schools merely needed new books every 10 years because of wear and tear. In any case, an initial comparison between the 1626 and the 1647 edition has not brought to light any significant changes.

Even if the 1625 School Order was legally valid in the various towns of the province of Holland, schoolmasters apparently had considerable freedom when implementing the specifics of the program. Thus, we do not know exactly how intensively De sphaera by Sacrobosco was studied in the different Latin schools, just as we are in the dark on whether the textbook was still used at university. The Leiden Orientalist and mathematician Jacob Golius (1596-1667), for example, taught a course elementa Astronomica exponit in September 1662 and in February 1663, but it remains unclear what books he used to this end (Molhuysen 1918, 174*, 176*). Other evidence on the use of De sphaera by students in the Dutch Republic has not yet turned up. ${ }^{75}$

The School Order would eventually not be implemented outside of the province of Holland, except partly in the city of 's-Hertogenbosch in Brabant, where, after the takeover by the Republican army, the authorities wanted to erect a new Latin

\footnotetext{
${ }^{74}$ (Kuiper 1958, 199): "Hyer sal geleert werden Logica Burgersdijck, Sphaera Johannis de Sacrobosco, Florus, Historia Graeca Herodiani, Virgilius, Horatius, Juvenalis etc."

${ }^{75}$ All the same, it is clear that the book was widely read. Christophorus Wittichius, for instance, literally copied a section on the vacuum in a dissertation on outer limits of the universe; (Wittichius 1653, 168-69): "Si caelum non esset...non essent figura orbiculari." Compare (Burgersdijk and de Sacrobosco 1626, 16-17). The dissertation by Wittichius was compiled in a book that would make him famous for bringing together the philosophy of René Descartes and the theology of the Gisbertus Voetius, a dogmatist neo-scholastic from the Gomarist faction.
} 
school to replace a Jesuit school with an excellent reputation. ${ }^{76}$ In the program for the new school, drafted in 1639, the original segment on Sacrobosco in the Holland School Order was replaced by some other mandatory measures. Nonetheless, the students had to follow a course over two or three years, reading De sphaera by Sacrobosco and the Logic by Burgersdijk, the Physics (Physiologiae Peripateticae libri sex) by Johannes Magirus (ca. 1560-1596), the Enchiridion Metaphysicum (1621) by Caspar Bartholin the Elder (1585-1629), The Compendivm Ethicae Aristotelice ad normam veritatis christiance revocatum by Antonius Walaeus, Justinus, Florus, and Sulpicius complemented with Johannes Sleidanus (1506-1556). ${ }^{77}$ Except for the classics, these were all well-known and determinedly Protestant writers who also appeared on the Holland School Order with the intent to counterbalance the Jesuit influence on the educational system.

\section{Conclusions}

Burgersdijk's neo-Aristotelianism was closely related to the rise of the ContraRemonstrant movement within the Dutch Reformed Church. Against that background, reflected in and articulated during the Synod of Dort and in Holland's School Order of 1625, the agenda of the last editor of De sphaera becomes clear: to produce a "clean" copy of a textbook that had proved its use for instruction, adapted to the needs of the young Protestant youth. In staunch competition with the Jesuits, Burgersdijk made an attempt to make the Dutch less dependent on Catholic literature and modes of knowledge production. Yet in reality, his neoLatin retranslation of the Sphaera effortlessly integrated many of the insights of the work by the Jesuit mathematician Christophorus Clavius. Indeed, Leiden neoAristotelianism was not substantially incompatible with Jesuit principles on all fronts. The outcome was that Dutch school pupils were still instilled with a geocentric worldview at a time when the heliocentric model had already become widely available.

\footnotetext{
${ }^{76}$ Even if it was not directly copied, the Holland Order did have an influence on the other provinces (Kuiper 1958, 161-73). I did not find any additional evidence for the use of De sphaera in (Bastiaanse, Bots, and Evers 1985; Bastiaanse and Evers 1986; Booy 1980).

${ }^{77}$ On the implementation of the school program in 's-Hertogenbosch, see (Kuiper 1958, 161-63). The direct influence of Holland School Order was clearly present (Kuiper 1958, 163): "Cum hos authores Scholarum Hollandicarum publicus ordo, quem hic noster, quam maxime potest, proxime imitatur, etiam praescripserit." Note that the original segment on geographical knowledge had disappeared.
} 


\section{Appendix}

Letter to the reader from (Burgersdijk and de Sacrobosco 1626, sig. a2-a2v).

Benevolo Lectori.

Cum illust. \& Potentes D D. Ordines Holandiae \& VVest-Frisiae decrevissent, ut iidem linguarum \& artium autores in omnibus scholis Hollandicis praelegerentur, inter caeteros libros Sphaeram Ion. de Sacro-Bosco censuerunt juventuti proponendam, ut ex eam adolescentes prima Astronomiae principia deliberarent, quam in Academiam deinde discerent plenius accuratiusque. Verum enim vero, cum hic autor no tam bonus esset, quam celebris, iidem Ordines nobis mandavarunt, ut eum inter multos alios libros scholis destinatos recenseremus, Latinatem que emendaremus. Cuirei, cum mihi obtigisset, ut admoverem manum, deprehendi statim, abstergeri non posse barbariem ab hoc autore, nisi totus, non in aliam linguam, sed in alium sermonem converteretur. Itaque sententiam Iohannis, quantum fieri potuit, meis verbis extuli, methodo etiam leviter emendata. Neque tamen hoc egi, ut sermone uterer elaborato, \& comto sed simplici \& facili, ac tantum non barbaro. Addidi praeterea multa ex aliis autoribus, praecipue ex Christophoro Clavio, qui $[\mathrm{a} 2 \mathrm{v}]$ doctissimis commentariis hunc nostrum illustravit, eaq; passim suis locis inserui, \& quo facilius à praeceptis autoris distinguerentur, alio charactere edenda curavi. Ad finem pauca quaedam adjeci de Theoricis Planetarum ex Georgio Purbachio, ut universae Astonomiae compendium, hoc libello contineretur. Neque tamen necessarium puto, haec omnia pueris inculcare (quaedam enim talia sunt, ut puerorum captum superent) sed praeceptorum judicio permittemdum censui, ut hinc petant, quae discipulorum suorum captui judicabunt esse accommodata. Unum etiam aut alterum Lucani testimonium, à Ioanne citatum, praeterii; quia Jospehus Scaliger in Prolegomenis in Manilium, Lucanum ipsum in iis locis erravisse, accuratè demonstravit. Nihil in toto hoc opere, benigne Lector, mihi vendico, praeter laborem \& studium; aliorum enim vestigiis institisse me, libenter profiteor. Neque laudem hinc capto aut gloriam. Hoc unum mihi laboris erit satis amplum praemium, si intellexero, studium meum tibi non improbari. Vale.

\section{References}

Abels, P.H.A.M. 2002. Duizend jaar Gouda: een stadsgeschiedenis. Hilversum: Verloren.

Appianus, Petrus. 1584. Cosmographia, siue descriptio vniuersi Orbis, Petri Apiani \& Gemmae Frisij, Mathematicorum insignium, iam demùm integritati suae restituta. adiecti sunt alij, tum Gemmae Frisij, tum aliorum auctorum eius argumenti tractatus ac libelli varij. Antwerp: Jean Bellère.

Balck, Everhardus. 1618. Album amicorum. Steinfurt/Franeker/Leiden [e.a.]: Koninklijke Bibliotheek: 75 A 2 / 1.

Bastiaanse, R.M., and Meindert Evers. 1986. Ontwikkelingen binnen het onderwijs aan de Gelderse Latijnse Scholen in de $17 \mathrm{e}$ en 18e eeuw. Bijdragen en mededelingen Vereniging Gelre 77: 68-91. 
Bastiaanse, René, Hans Bots, and Meindert Evers. 1985. Tot meesten nut ende dienst van de jeught: een onderzoek naar zeventien Gelderse Latijnse scholen, ca. 1580-1815. Zutphen: Walburg.

Bently, Lionel, and Martin Kretschmer. 2017. Resolutions concerning the Dutch school order, The Hague (1625-1626). Primary sources on copyright (1450-1900). www.copyrighthistory.org. Accessed June 2019.

Bos, Egbert P., and H.A. Krop, eds. 1993. Franco Burgersdijk (1590-1635): Neo-Aristotelianism in Leiden. Amsterdam: Rodopi.

Bot, Petrus Nicolaas Maria. 1965. Humanisme en onderwijs in Nederland. Utrecht: Spectrum.

Buning, Marius. 2019. Privileging the common good. The moral economy of printing privileges in the seventeenth-century Dutch Republic. In Buying and selling: The business of books in early modern Europe, ed. Shanti Grahelli, 88-108. Leiden: Brill.

Burgersdijk, Franco. 1645. Franconis BurgersdicI Institutionum logicarum synopsis, sive Rudimenta logica. In quibus pracipuce definitiones, divisiones, \& regulae, ad artem logicam pertinentes, per quaestiones \& responsiones, breviter \& dilucide proponuntur; in usum scholarum Hollandicarum. Leiden: Abraham Commelinus.

Burgersdijk, Franco, and Johannes de Sacrobosco. 1626. Sphaera Iohannis de Sacro-Bosco, decreto illustr. Et potent. D.D. Ordinum Hollandiae et West-Frisiae, in usum scholarum ejusdem provinciae sic recensita, ut \& Latinitas \& methodus emendata sit, multaque addita, quae ad huius doctrinae illustrationem requirebantur. Leiden: Bonaventura \& Abraham Elzevir. http://hdl.handle.net/21.11103/sphaera.101041.

- 1639. Sphaera Iohannis de Sacro-Bosco, decreto illustr. et potent. D.D. Ordinum Hollandiae et West-Frisiae, in usum scholarum ejusdem provinciae sic recensita, ut \& Latinitas \& methodus emendata sit, multaque addita, quae ad huius doctrinae illustrationem requirebantur. Leiden: Bonaventura \& Abraham Elzevir. http://hdl.handle.net/21.11103/sphaera.100589.

- 1647. Sphaera Iohannis de Sacro-Bosco, decreto illustr. et potent. D.D. Ordinum Hollandiae et West-Frisiae, in usum scholarum ejusdem provinciae sic recensita, ut \& Latinitas \& methodus emendata sit, multaque addita, quae ad huius doctrinae illustrationem requirebantur. Leiden: Bonaventura \& Abraham Elzevir. http://hdl.handle.net/21.11103/sphaera.100590.

- 1656. Sphaera Iohannis de Sacro-Bosco, decreto illustr. et potent. D.D. Ordinum Hollandiae et West-Frisiae, in usum scholarum ejusdem provinciae sic recensita, ut \& Latinitas \& methodus emendata sit, multaque addita, quae ad huius doctrinae illustrationem requirebantur. Leiden: Johannes Elzevir.

Casetti, Carla. 1993. Eliano, Vittorio. In Dizionario biografico degli italiani. Roma: Istituto della Enciclopedia italiana. http://www.treccani.it/enciclopedia/vittorio-eliano_(DizionarioBiografico)/. Accessed June 2019.

Cau, Cornelis, Simon van Leeuwen, Jacobus Scheltus, Paulus Scheltus, Isaac Scheltus, Didericus Lulius, and Joannes van der Linden (eds.). 1664. Groot placaet-boeck, vervattende de placaten, ordonnantien ende edicten van de doorluchtige, hoogh mog. heeren Staten Generael der Vereenighde Nederlanden ende vande ed. groot-mog. heeren Staten van Hollandt en WestVrieslandt, mitsgaders vande ed. mog. heeren Staten van Zeelandt: waer by noch ghevoeght zijn eenige placaten vande voorgaende graven ende princen de selver landen, voor soo veel de selve als noch in gebruyck zijn. Vol. 2. 9 vols. The Hague: weduwe ende erfgenamen van wylen Hillebrandt Jacobsz van Wouw [etc.].

Clavius, Christoph, and Joannes de Sacrobosco. 1570. Sphaeram Ioannis de Sacro Bosco commentarivs. Rome: Vittorio Eliano. http://hdl.handle.net/21.11103/sphaera.100365.

Clavius, Christoph, and Johannes de Sacrobosco. 1611. Christophori Clavii Bambergensis e Societate Iesu Operum mathematicorum V tomis distributa. Moguntiae [Mainz]: Hierat, Anton I. http://hdl.handle.net/21.11103/sphaera.100383.

Crowther, Kathleen M., and Peter Barker. 2013. Training the intelligent eye: Understanding illustrations in early modern astronomy texts. Isis 104 (3): 429-470. http://hdl.handle. net/10.1086/673269.

de Booy, Engelina Petronella. 1980. Kweekhoven der wijsheid: basis- en vervolgonderwijs in de steden van de provincie Utrecht van 1580 tot het begin der 19e eeuw. Zutphen: Walburg. 
Nijs, Thimo de, and Eelco Beukers. 2002. Geschiedenis van Holland. Vol. 2. 3 vols. Hilversum: Verloren.

Sacrobosco, Johannes de and Philipp Melanchthon. 1538. Ioannis de Sacro Busto libellus, De sphaera: Eiusdem autoris libellus, cuius titulus est Computus, eruditissimam anni \& mensium descriptionem continens. Cum praefatione Philippi Melanth. \& novis quibusdam typis, qui ortus indicant. Wittenberg: Joseph Klug. http://hdl.handle.net/21.11103/sphaera.101106.

Sacrobosco, Johannes de, Élie Vinet, Francesco Giuntini, and Pedro Nuñes. 1566. Sphaera Ioannis de Sacro Bosco emendata. Cum additionibus in margine, et Indice rerum et locorum memorabilium, et familiarissimis scholijs, nunc recenter compertis, et collectis à Francesco Iunctino Florentino sacrae Theologia Doctore. Interserta etiam sunt Eliae Vineti Santonis egregia Scholia in eandem Sphaeram. Adiunximus eiusdem auctoris Computum Ecclesiasticum. Et Petri Nonii Salaciensis demonstrationem eorum, quae in extremo capite de climatibus Sacroboscius scribit de inaequali climatum latitudine, eodem Vineto interprete. Antwerp: Heirs of Arnold Birckmann. http://hdl.handle.net/21.11103/sphaera.101115.

de Sacrobosco, Joannes, Elie Vinet, Pedro Nunes, and Pierio Valeriano. 1574. Sphaera Ioannis de Sacro Bosco emendata. Venice: Heirs of Girolamo Scotto. http://hdl.handle.net/21.11103/ sphaera.100309.

Sacrobosco, Joannes de, Christophorus Clavius, Élie Vinet, Albertus Hero, Francesco Giuntini, Pedro Nunes, and Pierio Valeriano. 1610. Sphaera Ioannis a Sacrobosco emendata, aucta et illustrata. Eliae Vineti Santonis, \& Francisci Iunctini Florentini scholia in eandem Sphaeram restituta. Quibus praeter Alberti Heronis scholia nunc accessere R. P. Christoph. Clavij breves commentarij. Adiunximus huic libro compendium in Sphaeram per Pierium Valerianum Bellunensem: et Petri Nonii Salaciensis Demonstrationem eorum, quae in extremo capite de climatibus Sacroboscus scribit de inaequali climatum latitudine, eodem Vineto interprete. Cologne: Peter Cholinus. http://hdl.handle.net/21.11103/sphaera.100357.

Dekker, E. 1993. Rijker dan Midas: vrijheid, genade en predestinatie in de theologie van Jacobus Arminius (1559-1609). Zoetermeer: Boekencentrum.

Dibon, Paul Auguste Georges. 1954. La philosophie Néerlandaise au siècle d'or. Amsterdam: Elsevier.

Dijksterhuis, Fokko. Jan. 2017. Duytsche Mathematique and the building of a new society: Pursuits of mathematics in the seventeenth-century Dutch Republic. In Mathematical practitioners and the transformation of natural knowledge in early modern Europe, ed. Lesley B. Cormack, Steven A. Walton, and John A. Schuster, 167-181. Cham: Springer. https://doi. org/10.1007/978-3-319-49430-2_9.

Dijkstra, Arjen. 2012. Between academics and idiots: A cultural history of mathematics in the Dutch province of Friesland (1600-1700). Ph.D. Leeuwarden: University of Twente.

Dongelmans, Berry P.M., Paul Gerardus Hoftijzer, and Otto Stephanus Lankhorst. 2001. Boekverkopers van Europa: het 17de-eeuwse Nederlandse uitgevershuis Elsevier. Zutphen: Walburg.

Emmius, Ubbo. 1951. Programma bij de aanvaarding van het rectoraat der Latijnse School (thans Praedinius-Gymnasium) te Groningen in 1594. Trans. Antoon Gerard Roos. Groningen: Wolters.

Feingold, Mordechai. 1993. The ultimate pedagogue: Franco petri Burgersdijk and the English speaking academic learning. In Franco Burgersdijk (1590-1635). Neo-Aristotelian in Leiden, ed. Egbert P. Bos and H.A. Krop, 151-165. Amsterdam: Rodopi.

Fortgens, H.W. 1958. Schola latina, uit het verleden van ons voorbereidend hoger onderwijs, door Dr. H.W. Fortgens. Zwolle: Tjeenk Willink.

Frijhoff, Willem, and Marijke Spies. 2004. Dutch culture in a European perspective: 1650, HardWon Unity. Assen: Van Gorcum.

Gilbert, Neal Ward. 1963. Renaissance concepts of method. New York: Columbia University Press.

Gingerich, Owen. 1999. Sacrobosco illustrated. In Between demonstration and imagination, ed. Lodi Nauta and A.J. Vanderjagt, 211-224. Leiden: Brill. 
Grant, Edward. 1994. Planets, stars, and orbs: The medieval cosmos, 1200-1687. Cambridge: Cambridge University Press.

Hamel, Jürgen. 2014. Studien zur Sphaera des Johannes de Sacrobosco. Leipzig: AVA.

Hoftijzer, Paul. 1993. Nederlandse boekverkopersprivileges in de $17 \mathrm{e}$ en $18 \mathrm{e}$ eeuw. Jaarboek Nederlands Genootschap Van Bibliofielen 1: 49-62.

Imhof, Dirk. 2014. Jan Moretus and the continuation of the Plantin press: A bibliography of the works published and printed by Jan Moretus I in Antwerp (1589-1610). Vol. 2. 2 vols. Leiden: Brill.

Israel, Jonathan Irvine. 1995. The Dutch Republic. Its rise, greatness, and fall, 1477-1806. Oxford: Clarendon.

Kaiser, Christopher B. 1988. Calvin's understanding of Aristotelian natural philosophy: Its extent and possible origin. In Calviniana: Ideas and influence of Jean Calvin, Sixteenth century essays \& studies Vol. 10, ed. Robert V. Schnucker, 77-93. Kirksville: Sixteenth Century Journal Publishers.

Krop, Henri. 2014. Burgersdijk, Franco. In Encyclopedia of renaissance philosophy, ed. Marco Sgarbi, 1-6. Cham: Springer. https://doi.org/10.1007/978-3-319-02848-4_271-1.

Kuiper, E.J. 1958. De Hollandse 'Schoolordre' van 1625: een studie over het onderwijs op de Latijnse scholen in Nederland in de 17de en 18de eeuw. Groningen: Wolters.

Kusukawa, Sachiko. 1995. The transformation of natural philosophy: The case of Philip Melanchthon. Cambridge: Cambridge University Press.

Lattis, James M. 1994. Between Copernicus and Galileo: Christoph Clavius and the collapse of Ptolemaic cosmology. Chicago: University of Chicago Press.

Metius, Adriaan Adriaansz. 1614. Institutiones Astronomicae et Geographicae. Fondamentale ende grondelijcke onderwysinge van de Sterrekonst, ende beschryvinghe der Aerden, door het ghebruyck van de Hemelsche ende Aerdtsche Globen. Amsterdam: Willem Jansz. Blaeu.

Mijers, Esther. 2017. Addicted to Puritanism: Philosophical and theological relations between Scotland and the United Provinces in the first half of the seventeenth century. History of Universities 29 (2): 69-96.

Molhuysen, Philip Christiaan, (ed.). 1913-1924. Bronnen tot de geschiedenis der Leidsche Universiteit. 1574-[1811]. Vol. 1. 7 vols. Rijks Geschiedkundige Publicatiën 20. The Hague: M. Nijhoff.

, (ed.). 1918. Bronnen tot de geschiedenis der Leidsche Universiteit. 1574-[1811]. Vol. 3. 7 vols. Rijks Geschiedkundige Publicatiën 20. The Hague: M. Nijhoff.

Molhuysen, Philip Christiaan, Petrus Johannes Blok, Laurentius Knappert, and Friedrich Karl Heinrich Kossmann. 1927. Nieuw Nederlandsch biografisch woordenboek. Vol. 7, 10. Leiden: Sijthoff.

Omodeo, Pietro D. 2017. Utilitas astronomiae in the renaissance: The rhetoric and epistemology of astronomy. In The structures of practical knowledge, ed. Matteo Valleriani, 307-331. Dordrecht: Springer. https://doi.org/10.1007/978-3-319-45671-3_12.

Orenstein, Nadine. 2006. Sleeping caps, city views and state funerals: Privileges for prints in the Dutch Republic 1580-1650. In In his milieu: Essays on netherlandish art in memory of John Michael Montias, ed. Amy Golahny, Mia M. Mochizuki, and Lisa Vergara, 313-346. Amsterdam: Amsterdam University Press.

Otterspeer, Willem. 2000. Het bolwerk van de vrijheid: De Leidse Universiteit, 1575-1672. Amsterdam: Bakker.

Ovid. 1989. Fasti. Cambridge, MA: Harvard University Press.

Pedersen, Olaf. 1985. In quest of Sacrobosco. Journal for the History of Astronomy 16 (3): 175221. https://doi.org/10.1177/002182868501600302.

Prak, Maarten Roy. 2005. The Dutch Republic in the seventeenth century: The golden age. Trans. Diane L. Webb. Cambridge: Cambridge University Press 
Prost, Joseph. 1907. La philosophie à l'Académie protestante de Saumur (1606-1685). Paris: H. Paulin. http://gallica.bnf.fr/ark:/12148/bpt6k55160737. Accessed June 2019.

Romano, Antonella. 1999. La contre-réforme mathématique. Constitution et diffusion d'un culture mathématique jésuite à la Renaissance (1540-1640). Rome: Bibliothèque des Ecoles françaises d'Athènes et Rome.

Rosen, Edward. 1974. Rheticus as editor of the Sacrobosco. In For Dirk Struik: Scientific, historical and political essays in honour of Dirk J. Struik, ed. Robert S. Cohen, J.J. Stachel, and Marx W. Wartofsky, 245-248. Berlin: Springer.

Ruestow, Edward Grant. 1973. Physics at seventeenth and eighteenth-century Leiden: Philosophy and the new science in the university. The Hague: Nijhoff.

Sacrobosco, Joannes, Élie Vinet, and Francesco Giuntini. 1573. Sphaera Ioannis de Sacro Bosco emendata. Cum additionibus in margine, et Indice rerum et locorum memorabilium, et familiarissimis scholijs, nunc recenter compertis, et collectis à Francesco Iunctino Florentino sacrae Theologia Doctore. Interserta etiam sunt Eliae Vineti Santonis egregia Scholia in eandem Sphaeram. Adiunximus eiusdem auctoris Computum Ecclesiasticum. Et Petri Nonii Salaciensis demonstrationem eorum, quae in extremo capite de climatibus Sacroboscius scribit de inaequali climatum latitudine, eodem Vineto interprete. Antwerp: Heirs of Arnold Birckmann. http://hdl. handle.net/21.11103/sphaera.101115.

Sassen, Ferd. 1959. Geschiedenis van de wijsbegeerte in Nederland tot het einde der negentiende eeuw. http://www.dbnl.org/tekst/sass011gesc01_01/. Accessed June 2019.

Schriks, C. F. J. 2015. The history of copyright in the Netherlands in the 16th-19th century: The book as legal entity and provincial and national legislation; state's copyright in the Netherlands in the 17th-21st century; public access in the Trias Politica and the right of copy and copyright. Zutphen: Walburg.

Simi, Nicolò. 1555. Theoricae planetarum in compendium redactae, et pluribus figuris auctae. Basel: Johannes Oporinus. https://doi.org/10.3931/e-rara-16422.

Smolenaars, Marja. 2004. Jack [Jacchaeus], Gilbert (Bap. 1577, d. 1628), philosopher and physician. In Oxford dictionary of national biography. http://www.oxforddnb.com/view/10.1093/ ref:odnb/9780198614128.001.0001/odnb-9780198614128-e-14512. Accessed June 2019

States of Holland. 1589. Placcaet inhoudende Verbot van te Drucken, ofte te stroyen, eenighe seditieuse boucken. Delft: Aelbrecht Hendricksz.

Stimson, Dorothy. 1917. The gradual acceptance of the Copernican theory of the universe. New Hampshire: Hanover. http://archive.org/details/gradualacceptanc00stimrich. Accessed June 2019.

Thorndike, Lynn. 1949. The Sphere of Sacrobosco and its commentators. Vol. 2. Chicago: University of Chicago Press.

Valerius, Cornelius. 1583. Grammaticarvm Institvtionvm liber IIII. Antverp: Plantin.

Valleriani, Matteo. 2017. The tracts on the Sphere: Knowledge restructured over a network. In The structures of practical knowledge, ed. Matteo Valleriani, 421-473. Dordrecht: Springer. https:// doi.org/10.1007/978-3-319-45671-3_16.

van Meurs, Johannes. 1625. Athenae Batavae. Sive, de vrbe Leidensi et academià, virisque claris; qui utramque ingenio suo, atque scriptis illustrarunt: libri dvo. Leiden: Andreas Cloucquius and Elsevirs.

Van Nouhuys, Tabitta. 1998. The ages of two-faced Janus: The comets of 1577 and 1618 and the decline of the Aristotelian world view in the Netherlands. Leiden: Brill.

van Wijckel, Hans. 1635. Album Amicorum. Franeker/Groningen/Leiden: Koninklijke Bibliotheek: $79 \mathrm{~J} 52$.

Vermij, Rienk. 2002. The Calvinist Copernicans: The reception of the new astronomy in the Dutch Republic, 1575-1750. Amsterdam: KNAW.

- 2016. Seventeenth-century Dutch natural philosophers on celestial influence. In Unifying heaven and earth essays in the history of early modern cosmology, ed. Miguel á Granada, Dario Tessicini, and Patrick J. Boner, 291-316. Universitat de Barcelona: Barcelona. 
Weekhout, Ingrid Marlies. 1998. Boekencensuur in de Noordelijke Nederlanden: De vrijheid van drukpers in de zeventiende eeuw. Den Haag: SDU.

Westman, Robert S. 1975. The Melanchthon circle, Rheticus, and the Wittenberg interpretation of the Copernican theory. Isis 66 (2): 165-193.

Wiesenfeldt, Gerhard. 2002. Leerer Raum in Minervas Haus: Experimentelle Naturlehre an der Universität Leiden, 1675-1715. Amsterdam/ Berlijn: Edita KNAW/Verlag für Geschichte der Naturwissenschaften und der Technik.

Willems, Alphonse. 1880. Les Elzevier: histoire et annales typographiques. Bruxelles: G.-A. van Trigt.

Witsenburg, K., and H.M. Van der Noordaa, eds. 1988. Catalogus van 125 Nederlandse Latijnse scholen. Almelo: Stichting Stadsherstel.

Wittichius, Christophorus. 1653. Dissertationes duae. Amsterdam: Abraham Elzevir.

Open Access This chapter is licensed under the terms of the Creative Commons Attribution 4.0 International License (http://creativecommons.org/licenses/by/4.0/), which permits use, sharing, adaptation, distribution and reproduction in any medium or format, as long as you give appropriate credit to the original author(s) and the source, provide a link to the Creative Commons license and indicate if changes were made.

The images or other third party material in this chapter are included in the chapter's Creative Commons license, unless indicated otherwise in a credit line to the material. If material is not included in the chapter's Creative Commons license and your intended use is not permitted by statutory regulation or exceeds the permitted use, you will need to obtain permission directly from the copyright holder. 